\title{
Birds of Parque Estadual Ilha do Cardoso: ecology, conservation and natural history
}

\author{
Henrique Chupil ${ }^{1 *(1)}$ \& Emygdio Leite de Araujo Monteiro-Filho ${ }^{1,2}$ \\ ${ }^{1}$ Instituto de Pesquisas Cananéia, Avenida Nina, 523, CEP 11.990-000, Cananéia, SP, Brasil. \\ ${ }^{2}$ Universidade Federal do Paraná, Centro Politécnico, Departamento de Zoologia, Caixa Postal 1901, CEP \\ 81.530-980, Curitiba, PR, Brasil. \\ *Corresponding author: hchupil@gmail.com
}

CHUPIL H., MONTEIRO-FILHO, E.L.A. Birds of Parque Estadual Ilha do Cardoso: ecology, conservation and natural history. Biota Neotropica 22(1): e20211295. https://doi.org/10.1590/1676-0611-BN-2021-1295

\begin{abstract}
The Parque Estadual Ilha do Cardoso (PEIC), located on extreme South of São Paulo's cost, in Brazil, holds an important Atlantic Forest remnant which still in a good state of conservation, but lack a deepen study about the avian community that habits the island. This study aimed to elaborate a census of avian species that occur in the park approaching richness, occurrence frequency, occurrence status and the structure of trophic guilds. A total of 25 field expedictions occurred between September 2015 and September 2017 during five days each, the field work included different ecosystems as mangrove, restinga, forest, sandbank, beach and marine. The census was made combine three different techniques used in ornithological studies: visual identification, auditory identification and catch by mist-nets (with five fixed sites in mangrove, restinga and forest). Were recorded 335 avian species, with 28 of them endemic from Brazil and 33 being threatened with extinction. Seventy-three species were recorded in all sampled months (FO 100\%), while 46 were recorded in just one month (FO $=4 \%$ ). About occurrence status, $55 \%$ of species are residents, $20 \%$ occasional visitors, $13 \%$ unusual residents, $6 \%$ migratory and $6 \%$ visitors. According the recorded species were recognized 25 trophic guilds based on food items, corporal size and strata that commonly forage, which of most representative in the community, the guild of "of insectivorous of mediumstrata" $(\mathrm{N}=55)$, "canopy omnivorous" $(\mathrm{N}=33)$, "aquatic invertebrates consummers" and "piscivorous" $(\mathrm{N}=$ 31). Finally, with the current study, we aimed through a significative field effort bring a better knowledge about avifauna of PEIC, which could be a good base when is necessary take actions that aim to park management and the Conservation Unities around it.
\end{abstract}

Keywords: Avifauna; Trophic Guilds; Mangrove; PEIC; Restinga.

\section{Aves do Parque Estadual Ilha do Cardos: ecologia, conservação e história natural}

Resumo: O Parque Estadual Ilha do Cardoso (PEIC), localizado no estremo sul do litoral paulista, reúne um importante remanescente de Floresta Atlântica em bom estado de conservação, carecendo, porém, de um estudo aprofundado sobre a comunidade de aves que habita a ilha. Diante disso, o presente estudo visou a elaborar um inventário das espécies de aves do parque abordando a riqueza, frequência de ocorrência, status de ocorrência e divisão das espécies em guildas. Foram realizadas entre setembro de 2015 e setembro de 2017, 25 expedições de campo com cinco dias de duração cada, incluindo os ecossistemas de manguezal, restinga, floresta, baixio, praia e marinho. O inventário foi realizado combinando três técnicas para estudos ornitológicos: identificação visual, identificação auditiva e captura com redes-de-neblina (cinco pontos fixos no manguezal, restinga e floresta). Foram registradas 335 espécies de aves, sendo 28 espécies consideradas endêmicas para o Brasil e 33 com algum grau de risco de extinção. Setenta e três espécies foram registradas em todos os meses amostrados (FO =100\%), enquanto que 46 apresentaram registros em apenas um mês $(\mathrm{FO}=4 \%)$. No que se refere ao status de ocorrência, $55 \%$ das espécies são residentes, $20 \%$ visitantes ocasionais, $13 \%$ residentes incomuns, $6 \%$ migratórias e $6 \%$ visitantes. As espécies registradas permitiram o reconhecimento de 25 guildas com base nos itens alimentares, tamanho corporal e estrato em que comumente forrageiam, sendo as mais representativas na comunidade, as guildas de "Insetívoros de estrato médio" $(\mathrm{N}=55)$, "Onívoros de copa" $(\mathrm{N}=33)$, "Consumidores de Invertebrados Aquáticos" e "Piscívoros" $(\mathrm{N}=31)$. Por fim, com o presente estudo, buscamos através de um significativo esforço em campo trazer um melhor conhecimento no que diz respeito a avifauna do PEIC, que pode vir a servir de base na hora de traçar ações visando ao manejo do parque bem como das unidades de conservação que se distribuem no seu entorno.

Palavras-chave: Avifauna; Guildas tróficas; Manguezal; PEIC; Restinga. 


\section{Introduction}

Biological communities correspond a set of organism's populations that inhabits a certain area and interact among each other and with the abiotic environment (Ricklefs 2016). The structure of a biological community, on a large scale, is determined basically by the biogeographic history of the organisms which composes it (Reif et al. 2010) and by climatic factors (Hawkins et al. 2003). In local level, their structure is influenced mainly by ecological relations, like interactions between the organism (Martin et al. 2016).

In terms of fauna, decrease in abundance of individuals and community loss of biological diversity occurs mainly due to environment structure alterations that affect fundamental portions of niches occupied by species (Karr \& Freemark 1983, Johns 1991). Such environment alterations, in the most cases, are associated with human activities, as habitats fragmentation, species introductions and the natural resources overexploitation (Primack \& Rodrigues 2001).

One of the most critic cases occur in Atlantic Forest, which initially covered almost all Brazilian coast, with a total area of 1.3 million $\mathrm{km}^{2}$, being currently restricted to less than $8.5 \%$ of its total (SOS Mata Atlântica 2015). In São Paulo's State, such biome originally covered $69 \%$ of its territory, however, as in another Brazilians states, had its area reduced, covering nowadays just $13.7 \%$ of this total and being restrict mainly to mountain and coastal regions remnants (SOS Mata Atlântica 2017).

Concerning biological diversity of Atlantic Forest, birds correspond of most representative vertebrate's group, with 927 species in southeastern Brazil, which 141 endemic species and 83 threatened with extintion (Ridgely et al. 2015). However, evaluating in a populational level, many of these species have a representative numeric decrease, being considered rare, because they live in restrict environment or for having a small geographical distribution (Goerck 1997). Thus, even though ecological and evolutional factors may justify the potential rarity of species, human actions seem to be the main aggravating factor in populational size decreasing (Develey 2004, Pereira et al. 2014, Morante-Filho et al. 2015).

Into this context, the Parque Estadual Ilha do Cardoso (PEIC), located on extreme South of São Paulo's coast, correspond to a good example of a landscape mosaic in a good state of conservation. However, just a few studies involving vertebrate's fauna, in community level, were made in the park, which were focused in herpetological fauna (Bertoluci et al. 2007, Rocha et al. 2008, Pinheiro 2009, Vilela et al. 2011, Prado 2012) and mammal fauna (Nakano-Oliveira 2006, Martins 2013, Silveira 2017). Concerning bird's communities, there is only a species list, that is in the management plan of the park (São Paulo 1998, 2002) and the Marsden et al. (2004) study which addresses the forest bird's community that inhabit the island. Therefore, based on assumption that there is a gap to be filled in the avifauna knowledge of PEIC, this study aims to elaborate a census of resident, migratory and occasional occurrence bird's species of the park and address aspects about richness, occurrence frequency, occurrence status and species division into guilds.

\section{Material and Methods}

\section{Study's area}

This study was developed in the Parque Estadual Ilha do Cardoso (PEIC), located on extreme South of São Paulo's coast (in $25^{\circ} 03^{\prime} 05^{\prime}$ ' to $25^{\circ} 18^{\prime} 18^{\prime \prime} \mathrm{S}$ and in $47^{\circ} 53^{\prime} 48^{\prime \prime}$ to $48^{\circ} 05^{\prime} 42^{\prime \prime} \mathrm{W}$; Figure 1$)$. The park belongs to the Cananéia city and was officially created from decree $\mathrm{n}^{\mathrm{o}} 40.319$ from $03 / 07 / 1962$. Has an area from approximately 13.300 hectares, with $30 \mathrm{~km}$ of extension in the portion which borders the Atlantic Ocean and with a maximum width $10 \mathrm{~km}$, showing an irregular shape which is larger in the North portion and becoming thin towards the South, where its ends with a slim portion of sand already on the Paraná's State border (Parque Nacional Superagui; Negreiros et al. 1974). The island's relief is very rugged, beginning on the sea level with modern sand ridges and reaching more than $800 \mathrm{~m}$ of elevation mountain range located on the island's central position, which its formation goes back to the Precambrian Period (Negreiros et al. 1974).

Inserted on Atlantic Forest biome, PEIC covers different ecosystems, as forest, restinga, mangrove, beach (considered here as sand portions without vegetations), sandbar (located over Ararapira's channel) and marine (channels which delimit the island on portions north and west as well in the east marine portion of the island). In this study, we considered as "restinga" areas starting from herbaceous and shrub vegetation located in high tide limit to the most arboreous portion featured to still present sandy soil with a thin layer of litterfall. In addition, we considered "forest" as the formations present starting from ecotone limit with restinga, encompassing flatland forest and hillside forest (or from Serra do Mar).

The region's weather, which include both areas, is featured as hot and humid, with an average thermal amplitude from $17^{\circ} \mathrm{C}$ to $26^{\circ} \mathrm{C}$ and an average monthly rainfall of $157 \mathrm{~mm}$ (recorded from 2002 to 2016; CIIAGRO 2017). The region presents predominance of tropical air masses in summer and a discrete predominance of polar air masses in winter (Schaeffer-Novelli et al. 1990).

Specifically, in Ilha do Cardoso, the weather shows some particular features, especially with regard to variations in rainfall levels and temperature. According Negreiros et al. (1987) these variations are due to local factors, such as maritimity, rugged topography and vegetation characteristics.

\section{Sample design}

A total of 25 field expedictions occurred between September 2015 and September 2017 during five days each SISBIO license 39328-8 and COTEC 277/2016). The field started at 06:00 AM and extended until 18:00 PM, being carried out in ecosystems such as mangrove, restinga and forest, located in north east of island (Figure 1). Short nocturnal incursions were made on these ecosystems aim to register birds from Orders Strigiformes, Caprimulgiformes e Nyctibiiformes. The sandbar, beach and channel which separate Ilha de Cananéia from Ilha do Cardoso were sampled once a month by onboard incursions and by walk in sand strip on northern portion of the island (Pereirinha's beach). The species that were recorded only flying over any of the mentioned ecosystems were categorized as "flying", since it was impossible to determine whether the species was just moving or occupied the ecosystem in question.

The inventory was carried out by combining three ornithological studies techniques: visual identification, auditory identification as catch by mist-nets. The mist-nets were placed in fixed sites during two consecutive days in the main three ecosystems which compose the island on the northeast portion: mangrove (on the Perequê's river mouth), restinga (over a road and Morro das Almas trail) and forest 


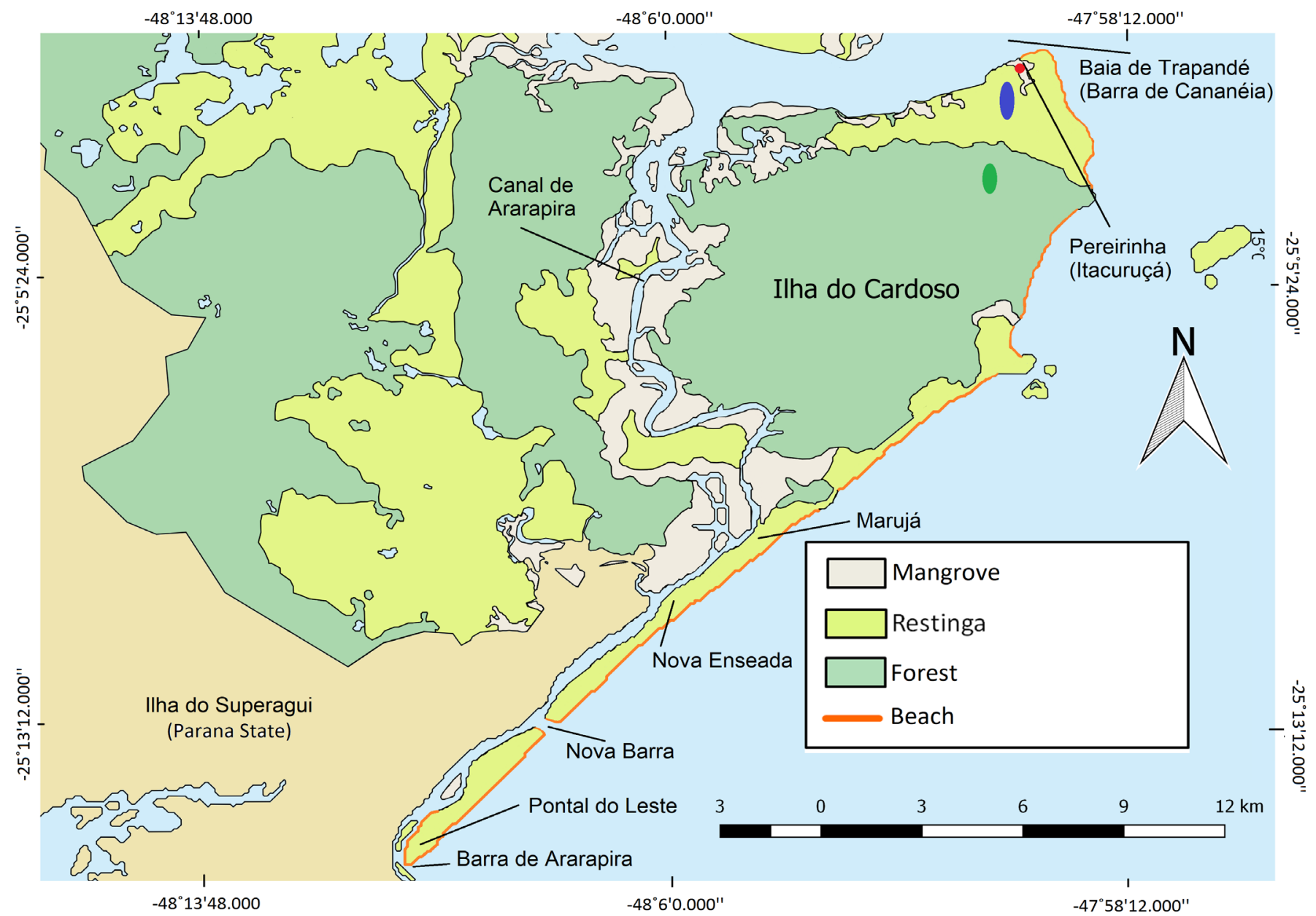

Figure 1. Sites localization's where was used mist-nets in Northeast portion of Ilha do Cardoso, South coast of São Paulo’s State $(\bullet$ mangrove, $\bullet$ restinga e $\bullet$ forest $)$.

(next to an old house which was used as electric power center). For this, six mist-nets were used in each ecosystem (Figure 1) (stitch of 19, 20, 25 and $30 \mathrm{~mm}$ ), which were opened at 06:00 AM. and closed at 18:00 PM. Mist-nets were reviewed each 25 minutes aimed to take the specimen that were catched by it to identify and mark with rings. All captured birds were marked in the right tarsus with metal rings provided by CEMAVE (ringing authorization 3999).

Was also included species which were identified by picture records made by local residents and by Projeto Monitoramento de Praias Bacia de Santos (PMP-BS) which monitors beaches of Ilha do Cardoso everyday. In addition, including species recorded in the period from September 2017 to December 2020 observed in field expeditions without a defined frequency. For the three situations were excluded of occurrence frequency calculation. The taxonomy classification used followed the proposal by the Brazilian Comitee of Ornithological Records (Pacheco et al. 2021).

\section{Data analysis}

The occurrence frequency was calculated by $\mathrm{FO}=\mathrm{A} / \mathrm{n} .100$, where " $A$ " means number of months that a specie was recorded and " $n$ " is the number of total months sampled $(\mathrm{N}=25)$. Occurrence status was defined in this study after analyzing the occurrence of the species over the sampled period, with the occurrence frequency results calculated and information available in the literature (Sick 2001, Pacheco et al.
2021). It was considered as Residents birds with FO above $20 \%$ or more; Unusual Residents, those which present FO above $10 \%$ but under $20 \%$; Occasional Visitors, those species that besides doesn't show presence/absence patters defined, presented FO under 10\%; Migratory those species with FO above or equal $20 \%$ and that show a clear similar pattern of presence/absence over the two sampled years. Species on migratory routes that used the area for a brief period and that is, in this study, showed FO under 10\%, was classified as Visitors from North Hemisphere and Visitors from South Hemisphere, following what was purposed by Pacheco et al. (2021).

We used here the status "Unusual Resident" (FO over 10\%), by the fact however a species has not been recorded on certain months, we cannot simply affirm that such specie is not occurring in that area at that time, once their "absence" could be just associated to their low conspicuity (Marterer 1996). The difference in "Unusual Resident", therefore, to refer to those less conspicuous in the area (or potentially rare). Concerning birds classified as "Migratory", was related to their behavior on Ilha do Cardoso, that could differ to the general pattern described in literature.

The species division in guilds was grounded in the concept proposed by Willis (1979) with some adequations aimed to encompass all community. For this was adopted some information available in Sick (2001) and Kissling et al. (2011), besides the observations made in 
field. The classification considered the predominant diet items in each specie, the body size and the main strata that they foraging: LSF (Large Soil Frugivores), LTF (Large Canopy Frugivores), STF (Small and Medium Canopy Frugivores), MSF (Medium Strata Frugivores), AO (Aquatic Omnivores), MSO (Medium-Strata Omnivores), CO (Canopy Omnivores), SO (Soil Omnivores), UO (Understory Omnivores), P (Piscivores), DC (Daytime Carnivores), NC (Nocturnal Carnivores), AIC (Aquatic Invertebrate Consumers), TIC (Terrestrial Invertebrates Consumers), SI (Soil Insectivores), MSI (Medium-Strata Insectivores), UI (Understory Insectivores), CI (Canopy Insectivores), DAI (Daytime Aerial Insectivores), NAI (Nocturnal Aerial Insectivores), S (Scavengers), SG (Soil Granivores), UG (Understory Granivores), MSG (Medium-Strata Granivores) and N (Nectarivores).

To test if there was a significative difference in species richness in ecosystems between years and seasons, was used a Permutational Multivariate Analysis of Variance (PERMANOVA), which factors (years and season) were considered as fixed effects and number of permutations used was 9.999. This analysis was made using software "Past" (Hammer et al. 2001), where similarity matrix by similarity coefficient of Jaccard was constructed with richness data. Seasons was grouped in: December, January and February (summer); March, April and May (fall); June, July and August (winter); September, October and November (spring) for better attending region's characteristics. An accumulation curve was made based in species richness data (presence/ absence matrix) in function of the number of sampling, aimed to observe whether the community has already been sampled satisfactorily.

\section{Results}

In the end of the 25 sampled months, were totalized 1.500 hours in field, distributed in 125 days. Concerning captures, were 1.116 hours of open mist-nets, of which 588 hours were on mangrove, 576 on restinga and 576 hours on the forest. As result of strong rainfall, for a day on mangrove, two days on restinga and four days on forest the mist-nets were not opened.

Was recorded 335 bird species belonging to 25 orders and 75 families (Table 1). Of these, seven were identified through pictures made by island's locals: Amazonetta brasiliensis (Brazilian Teal), Limosa haemastica (Hudsonian Godwit), Ramphastos dicolorus (Redbreasted Toucan), Sturnella superciliaris (White-browed Meadowlark), Himantopus melanurus (White-backed Stilt), Notharcus swainsoni (Buff-bellied Puffbird) e Schistochlamys ruficapillus (Cinnamon Tanager). More seven species were included based on records made by Projeto Monitoramento de Praias - Bacia de Santos (PMP-BS) executed by Instituto de Pesquisas Cananéia (IPeC): Spheniscus magellanicus (Magellanic Penguin), Thalassarche chlororhynchos (Yellow-nosed Albatross), Thalassarche melanophris (Black-browed Albatross), Macronectes giganteus (Southern giant-Petrel), Macronectes halli (Northern giant-Petrel), Procellaria aequinoctialis (White-chinned Petrel) e Calonectris borealis (Cory's Shearwater). In addition, six species were recorded in the period from September 2017 to December 2020 during field expeditions without a defined frequency, being them: Tringa solitaria (Solitary Sandpiper), Tringa melanoleuca (Greater Yellowlegs), Tringa semipalmata (Eastern Willet), Tringa flavipes (Lesser Yellowlegs), Jacana jacana (Wattled Jacana) and Parabuteo unicinctus (Harris's Hawk). Based on records made in field (excluded those made by pictures and after September 2017), accumulation curve for Ilha do Cardoso stabilizes from 23th sampling (Figure 2). Among recorded species, 28 are considered endemic from Brazil (Pacheco et al. 2021) and 33 threatened with extinction whether in state level (Silveira et al. 2009), national (MMA 2014) or worldwide (IUCN 2018) (Table 2).

Was captured 628 birds from 81 species belonging to eight orders and 29 families. From total captures, 88 correspond to recaptures. Concerning ecosystems, on mangrove were captured 263 birds belonging to 46 species, on restinga 209 birds belonging to 45 species and 156 on forest belonging to 30 species.

Ecosystems species richness showed significant differences between sampled years $(\mathrm{df}=1, F=4,82, P=0,0026)$ and seasons $(\mathrm{df}=3, F$ $=7,27, P=0,0004$ ). Between September to December (spring) was possible to register the largest number of species in both years, with a peak on November. In contrast, between May to August (winter) was recorded the lowest numbers of species in the area, with minimum values on June (Figure 3).

Between sampled ecosystems (including the six species recorded after September 2017), the restinga showed largest richness $(\mathrm{N}=232)$, followed by forest $(\mathrm{N}=145)$, mangrove $(\mathrm{N}=118)$, beach $(\mathrm{N}=42)$, sandbar $(\mathrm{N}=30)$, marine $(\mathrm{N}=15)$ and flying $(\mathrm{N}=11)$. Except sandbar, all others present species recorded only in their own ecosystem: restinga $(\mathrm{N}=77)$, forest $(\mathrm{N}=36)$, beach $(\mathrm{N}=20)$, mangrove $(\mathrm{N}=14)$, flying $(\mathrm{N}=11)$ and marine $(\mathrm{N}=3)$ (more details on Table 1$)$.

Regarding occurrence frequency (FO) (excluded 20 species identified by pictures records or after September 2017), 73 species were recorded in all sampled months $(\mathrm{FO}=100 \%)$, while 46 showed records in just a month ( $\mathrm{FO}=4 \%$ ) (APPENDIX 1). Concerning occurrence status, $55 \%$ of species are residents, $20 \%$ occasional visitors, $13 \%$ unusual residents, $6 \%$ migratory, $4 \%$ visitors from North hemisphere and $2 \%$ visitors from South hemisphere (Table 1).

According to 335 recorded species added to the six species recorded after September 2017, was possible recognize 25 guilds based in food items, body size and strata that commonly forage, being the most representative in the community, the guilds "Medium-Strata Insectivores" ( $=55)$, "Canopy Omnivores" $(\mathrm{N}=33)$, "Piscivores" $(\mathrm{N}=31)$ and "Aquatic Invertebrate Consumers" $(\mathrm{N}=31)$ (Table 3). When analyzing the distribution inside of mangrove, restinga and forest ecosystems, the predominant guild is "Medium-Strata Insectivores" as well, while in the sandbar, beach and marine was "Piscivores". In flying it was possible to observe the predominance of "Daytime Aerial Insectivores".

\section{Discussion}

The expressive number of recorded species in Parque Estadual Ilha do Cardoso (PEIC; $\mathrm{N}=335$ ) represents well the biome's diversity and the Atlantic Forest remnants of South coastal region of São Paulo's State, corresponding to $35.4 \%$ avifauna of the biome in the Brazil Southern and $17 \%$ of all Brazilian's avifauna. Furthermore, the sum of the different ecosystems (mangrove, restinga, forest, beach, sandbar and marine) and in a good conservation state, contribute directly to the highly richness. Still stands out the fact of to shelter 28 endemic species, 33 species in some level endangered and species which indicates that the environment still in a good conservation's state, as Aburria jacutinga (Black-fronted 


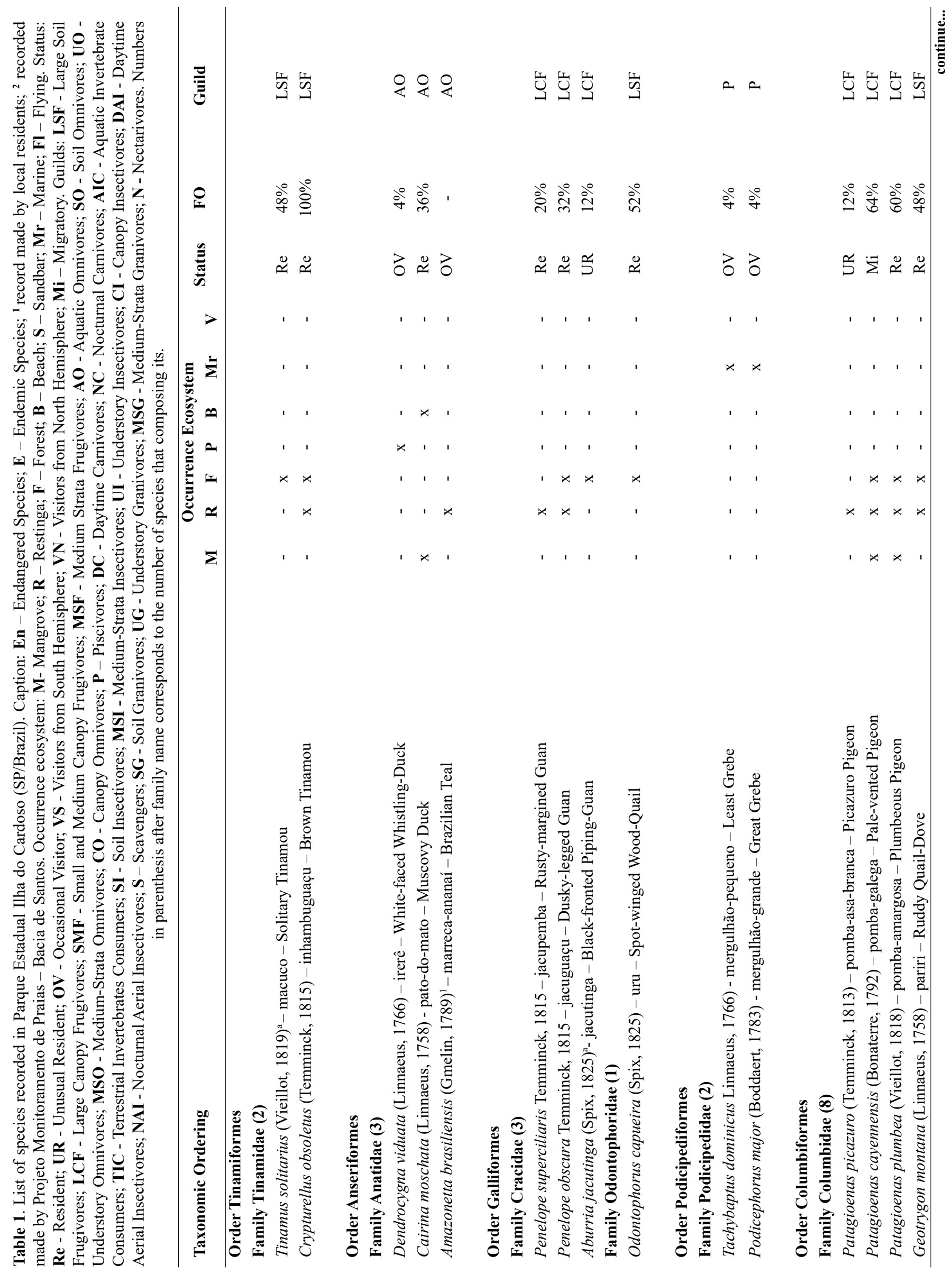


Chupil \& Monteiro-Filho

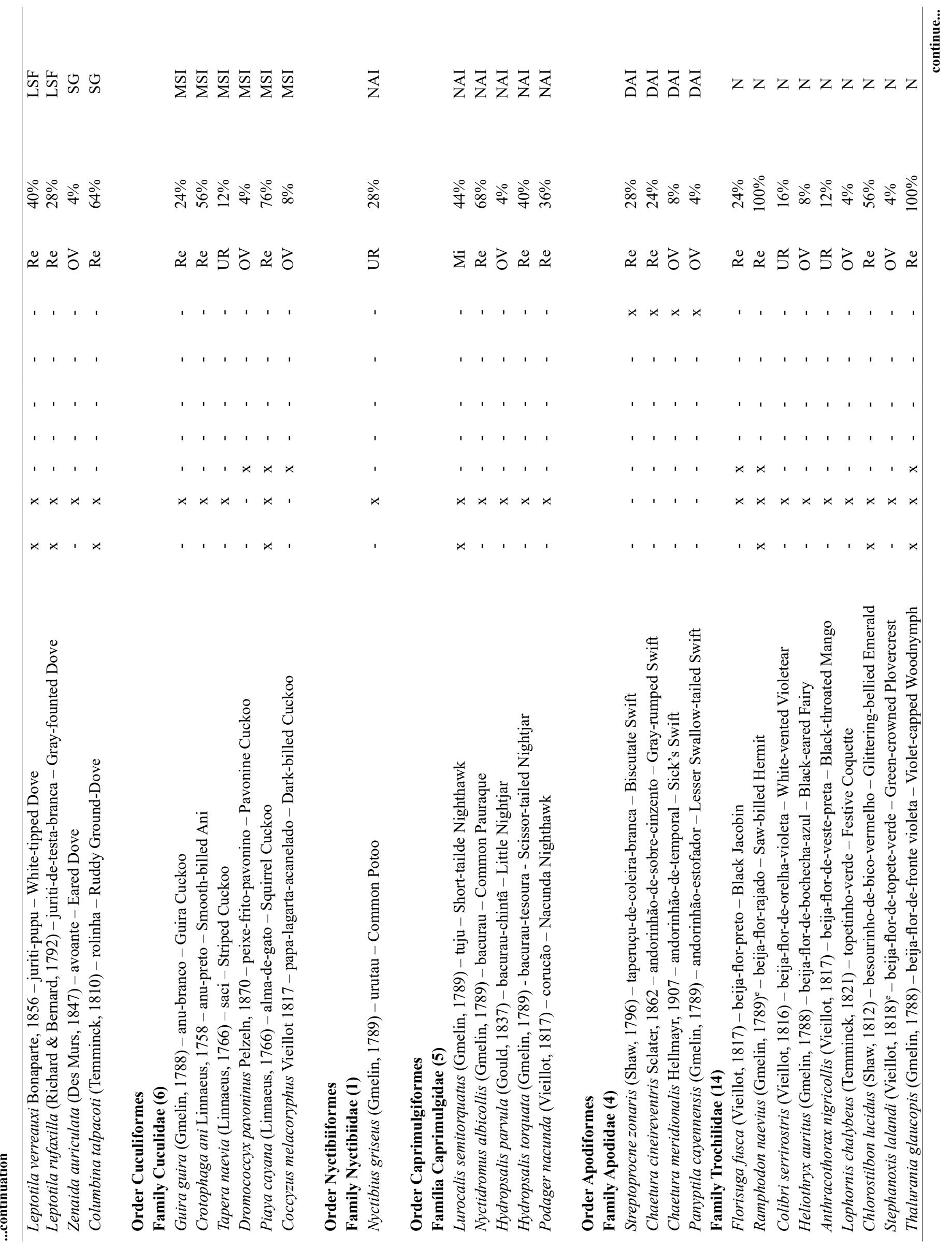




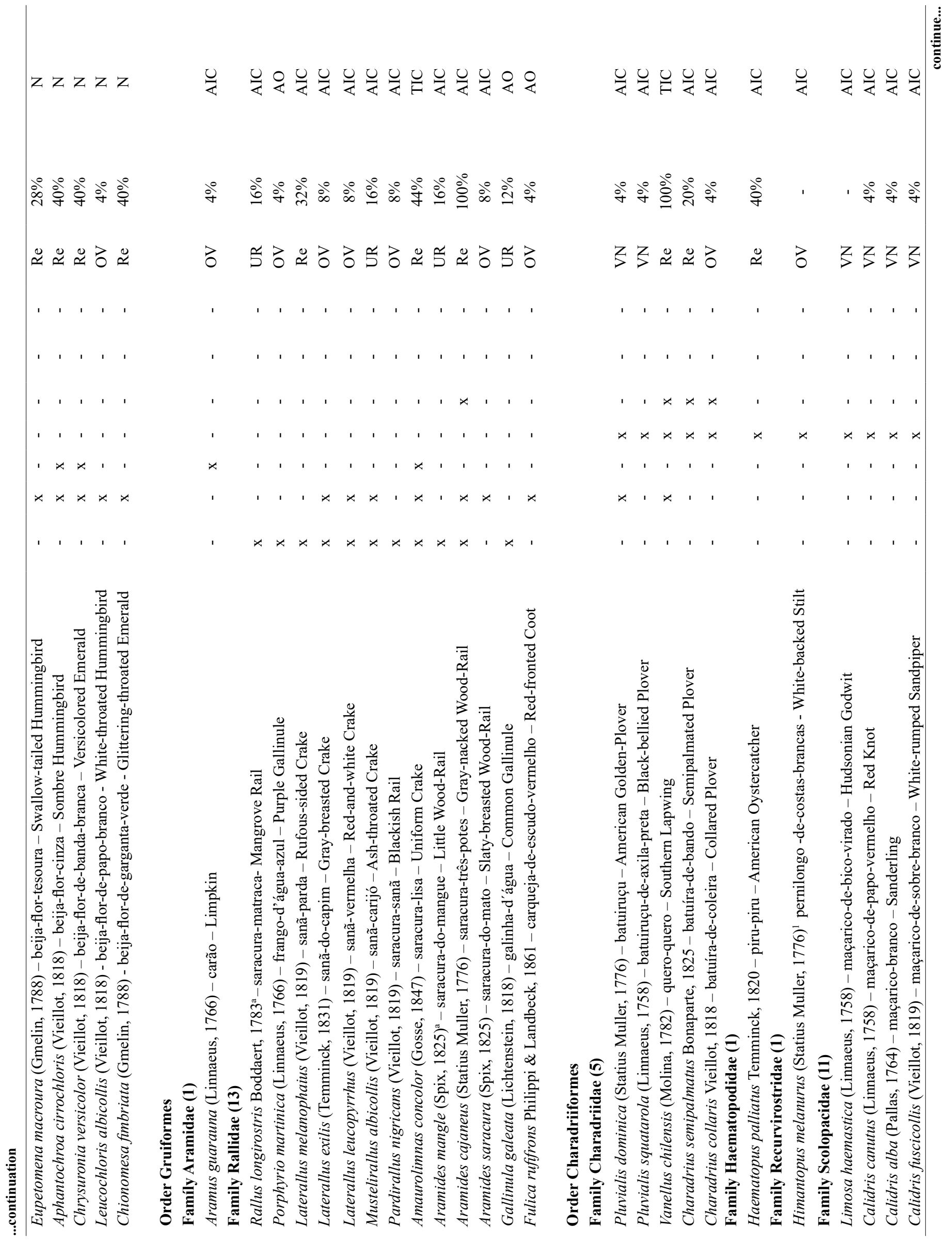




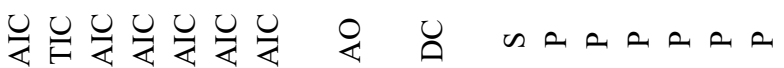

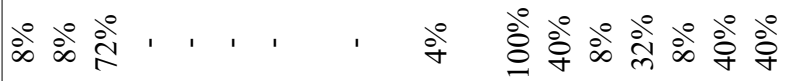

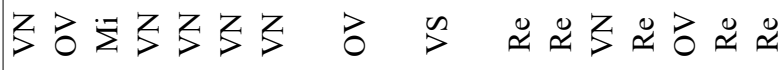

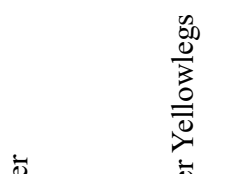

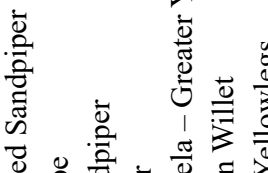

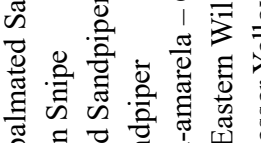

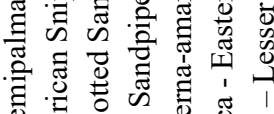

की

\& 1 :

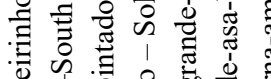

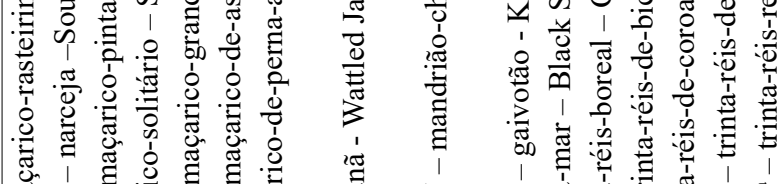

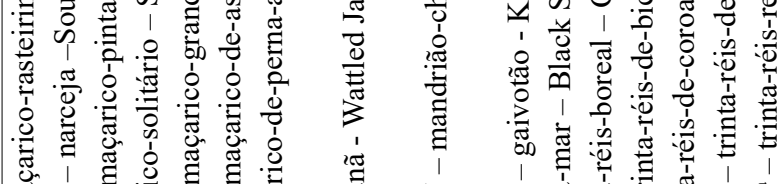

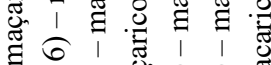

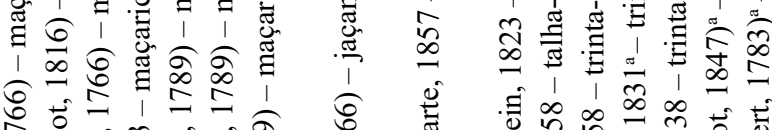

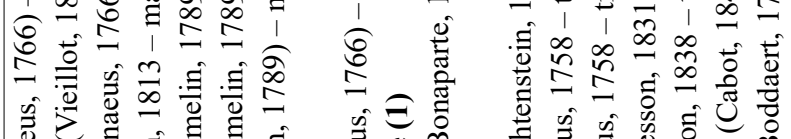

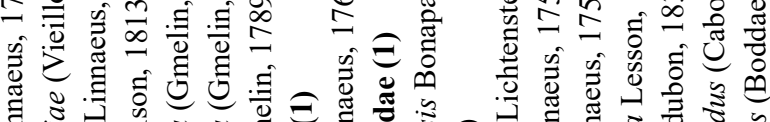

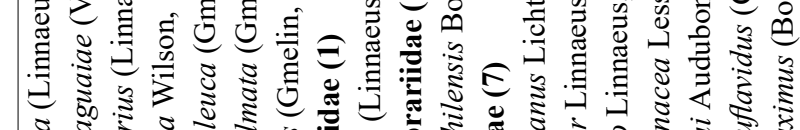

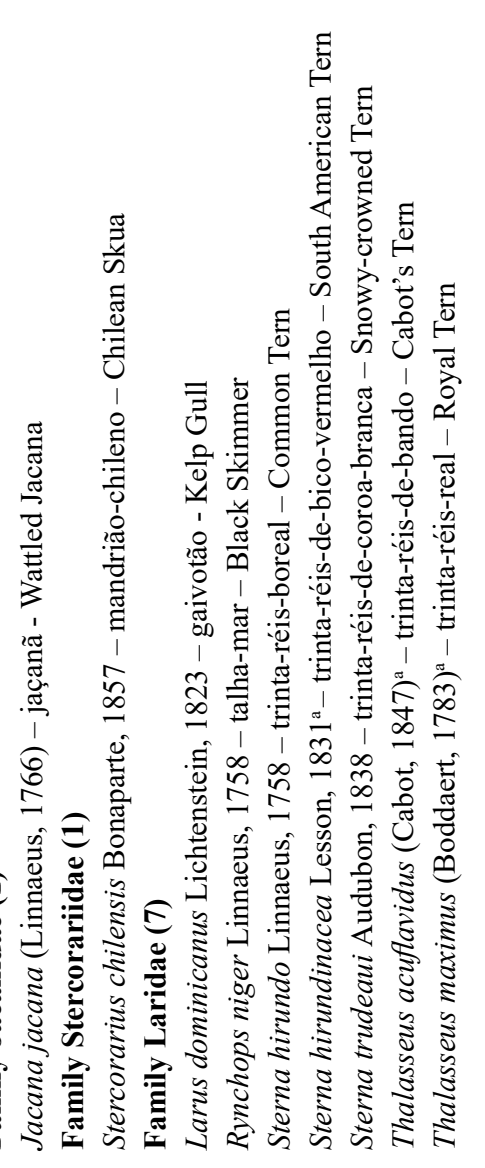

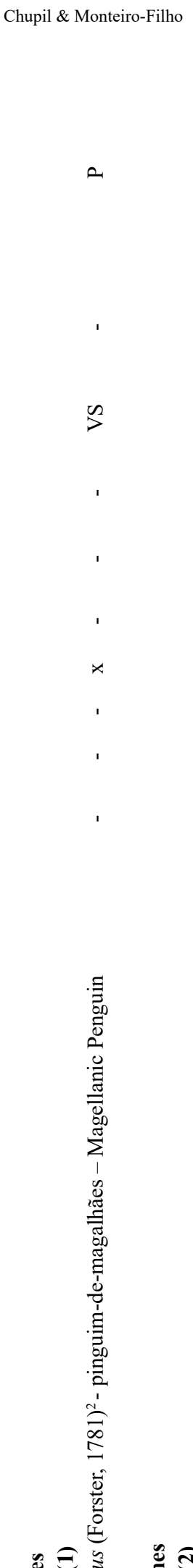

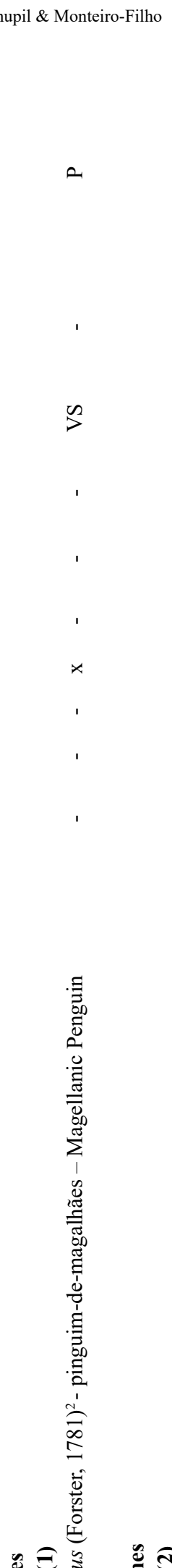

a \& ¿ूan

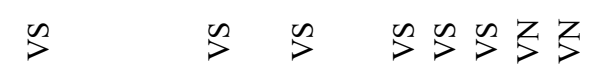

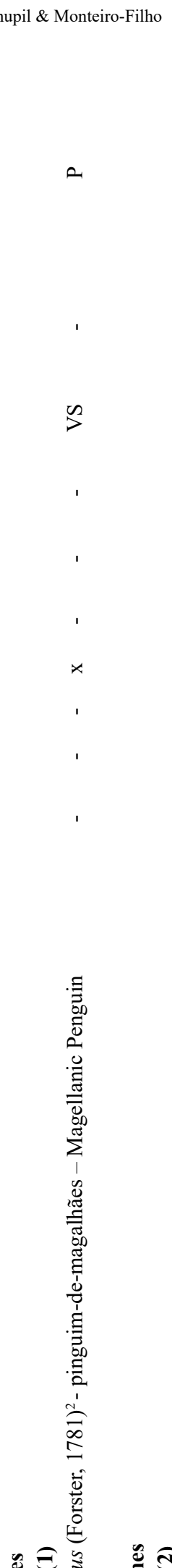
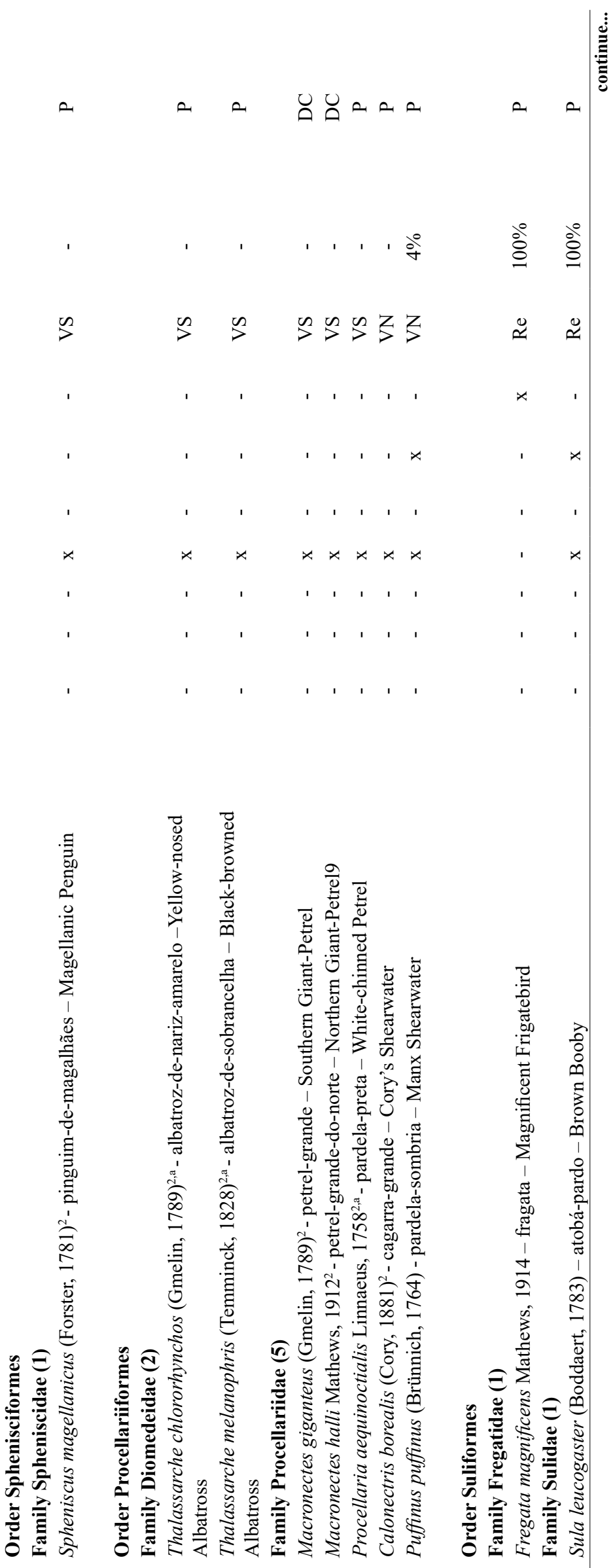
Birds of Parque Estadual Ilha do Cardoso

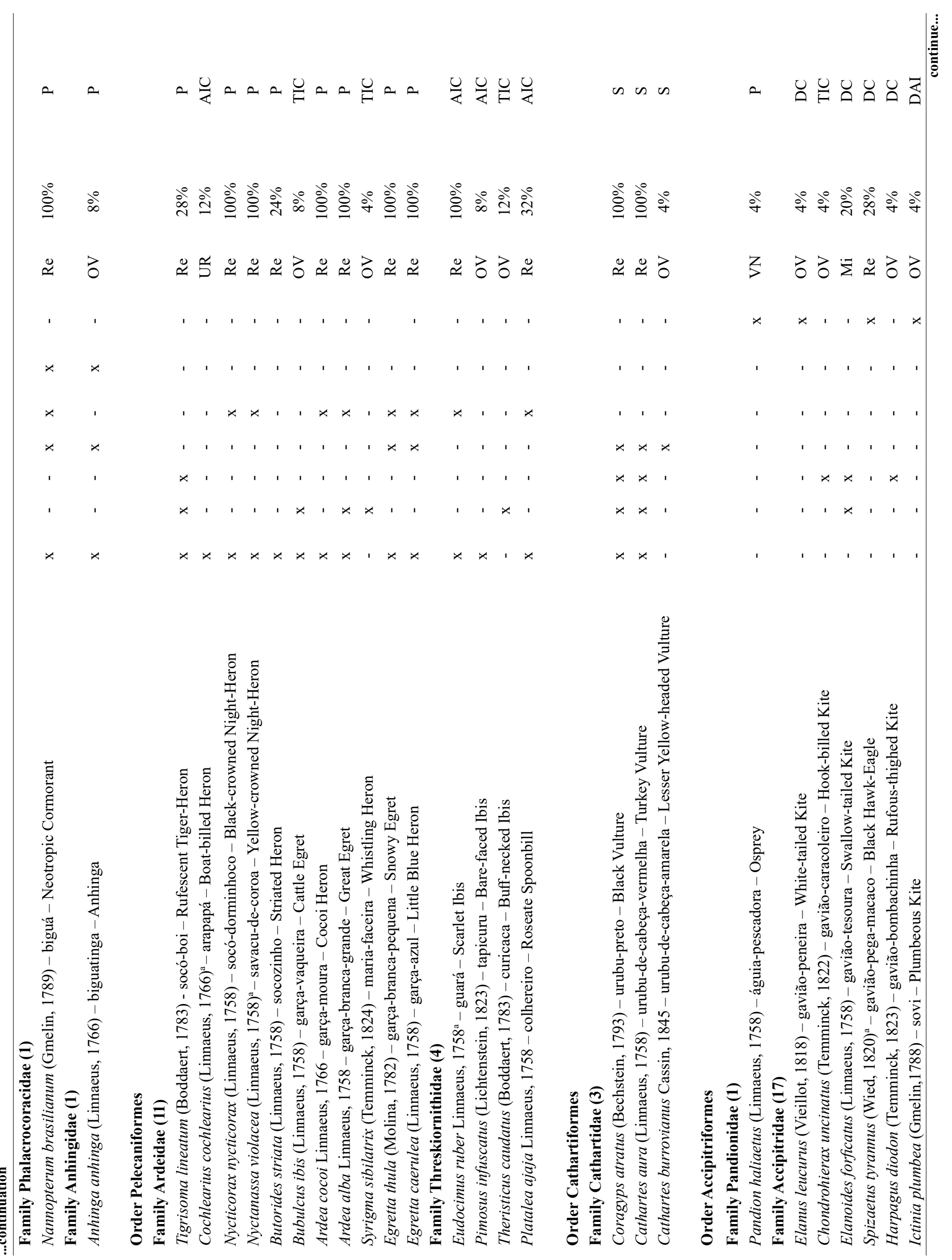


Chupil \& Monteiro-Filho

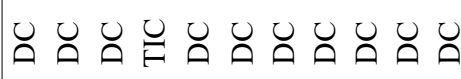

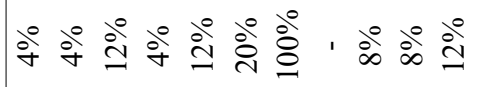

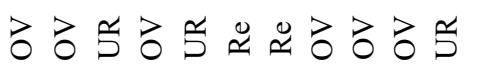

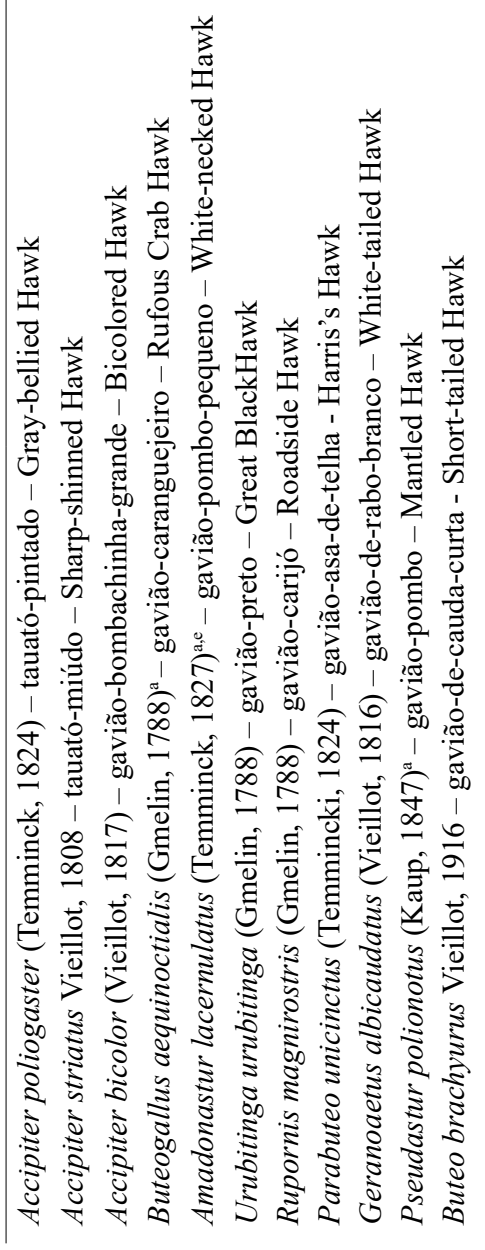

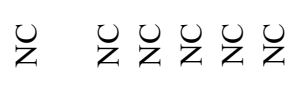

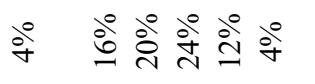

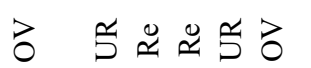

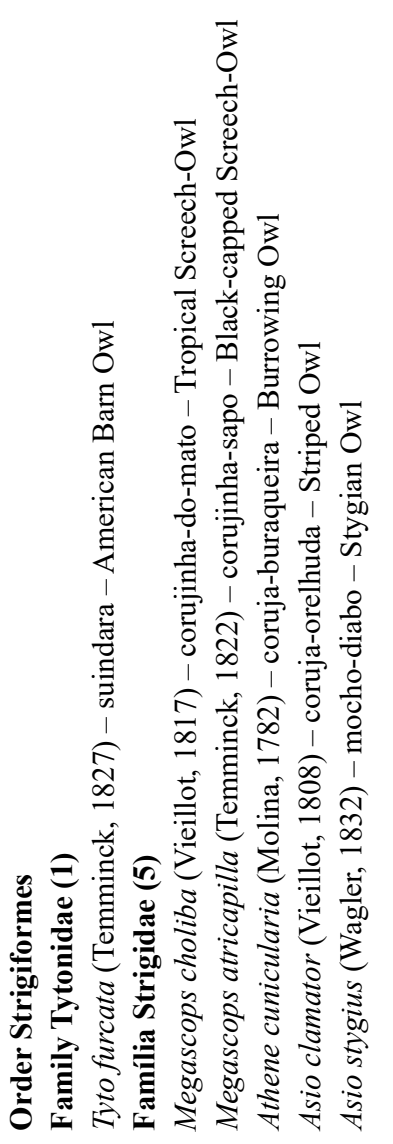

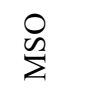

$\times$

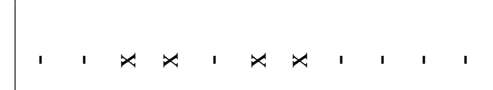

http://www.scielo.br/bn

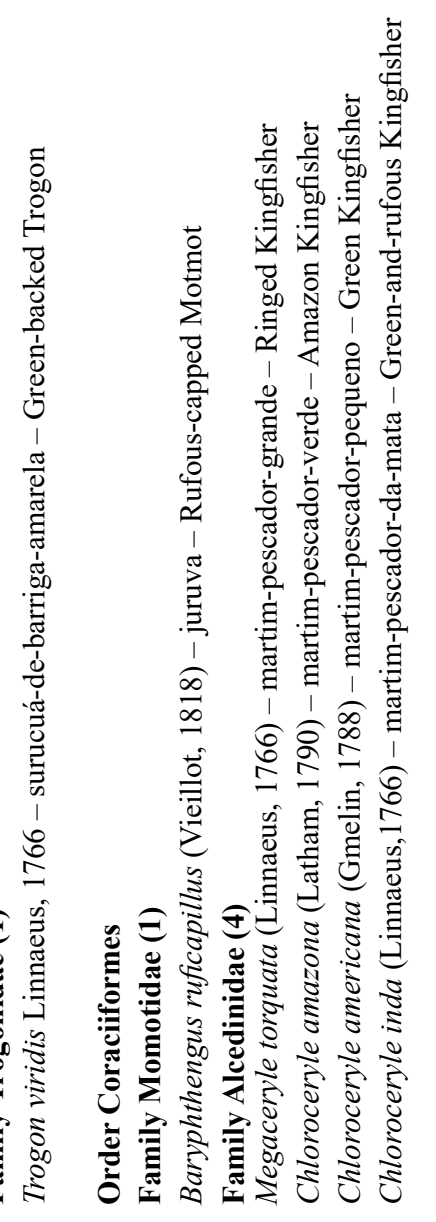

$\mathscr{O} a \operatorname{ar}$

ㅇํㅇ

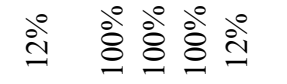

$\check{5} \approx \cong \because \check{5}$

$\dddot{m}$

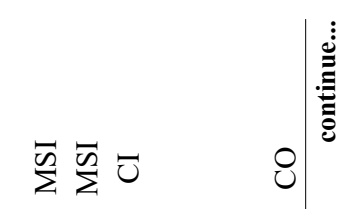

ذั่

ริ $\vec{b}$

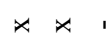

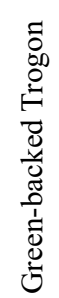
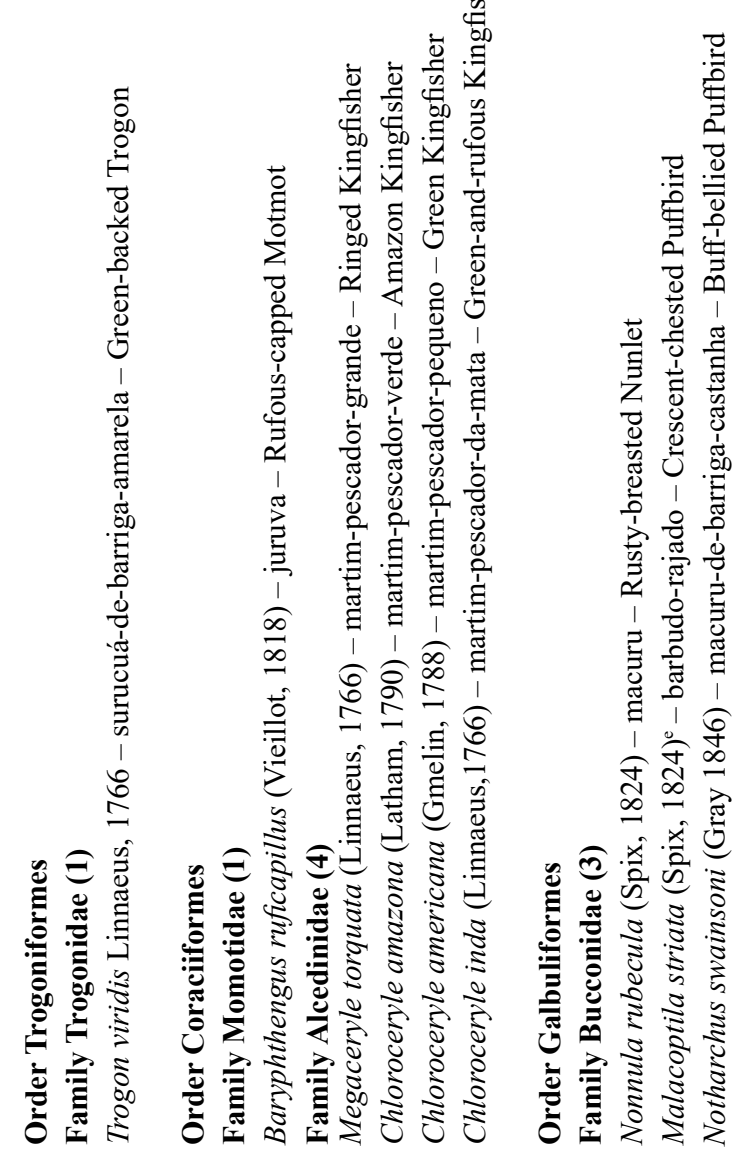
Birds of Parque Estadual Ilha do Cardoso

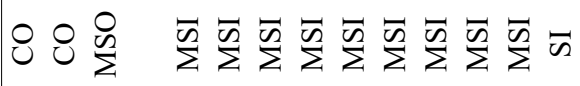

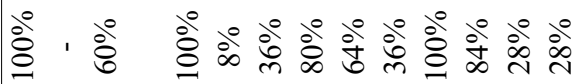

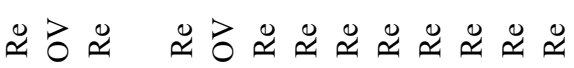

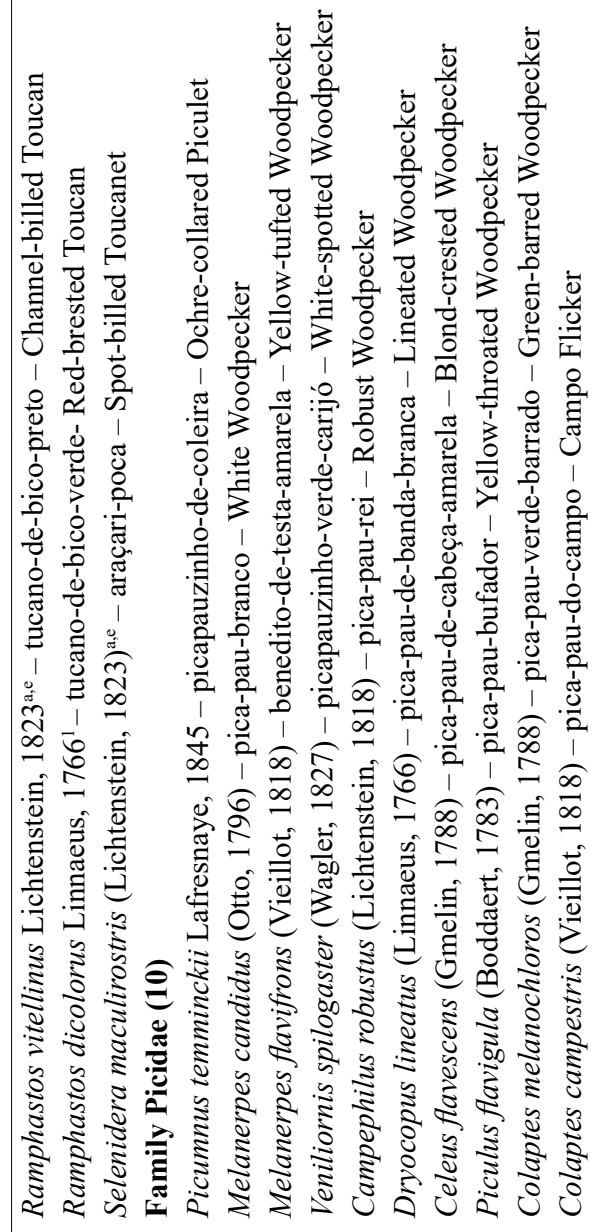

$x \times x$

(1)

.

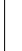

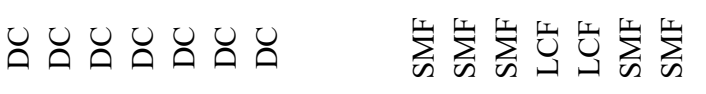

https://doi.org/10.1590/1676-0611-BN-2021-1295

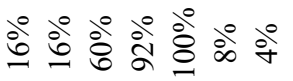

$\tilde{5} \tilde{5} \cong \approx z b$
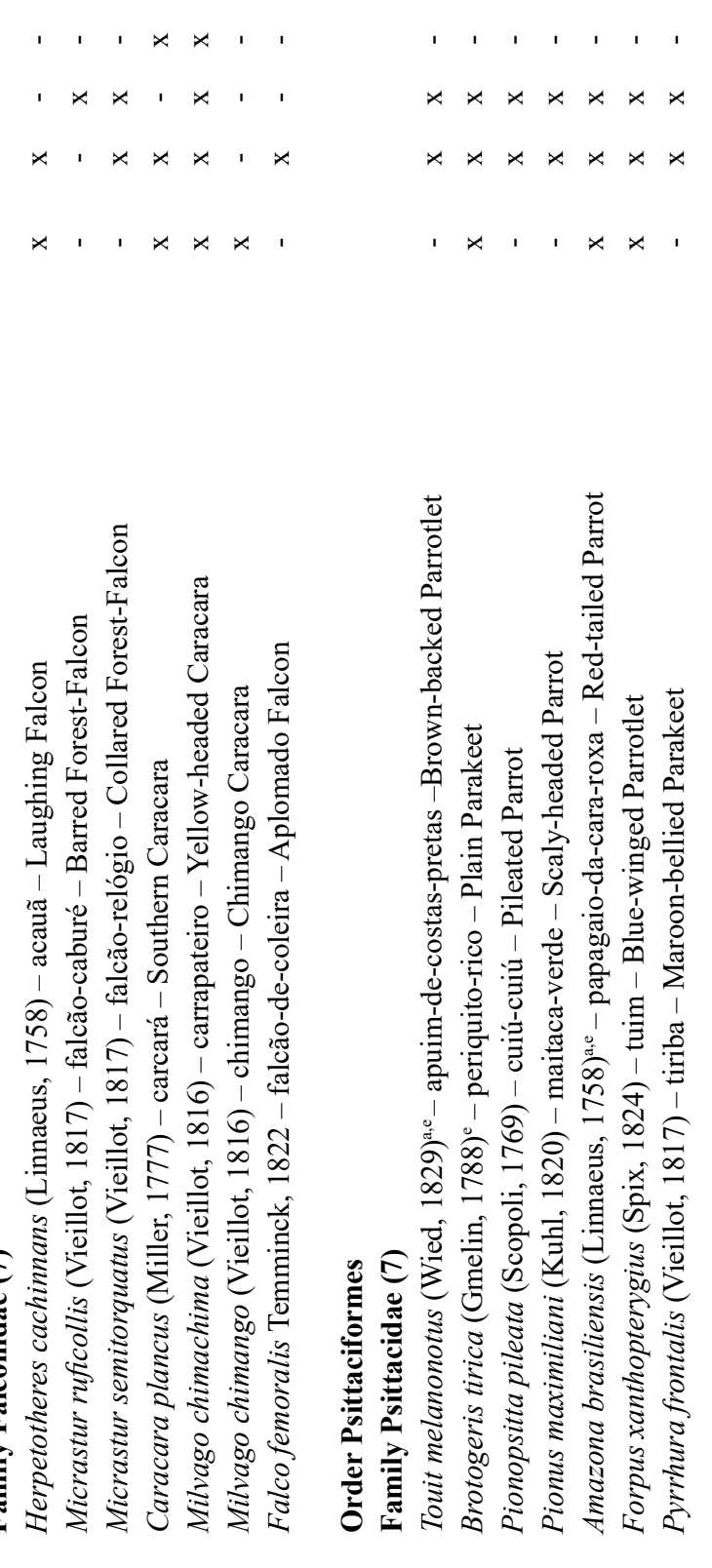

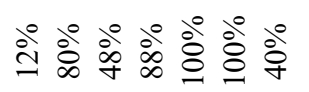
$\tilde{5} \approx \approx \approx \approx \approx ⿻ 上 丨$
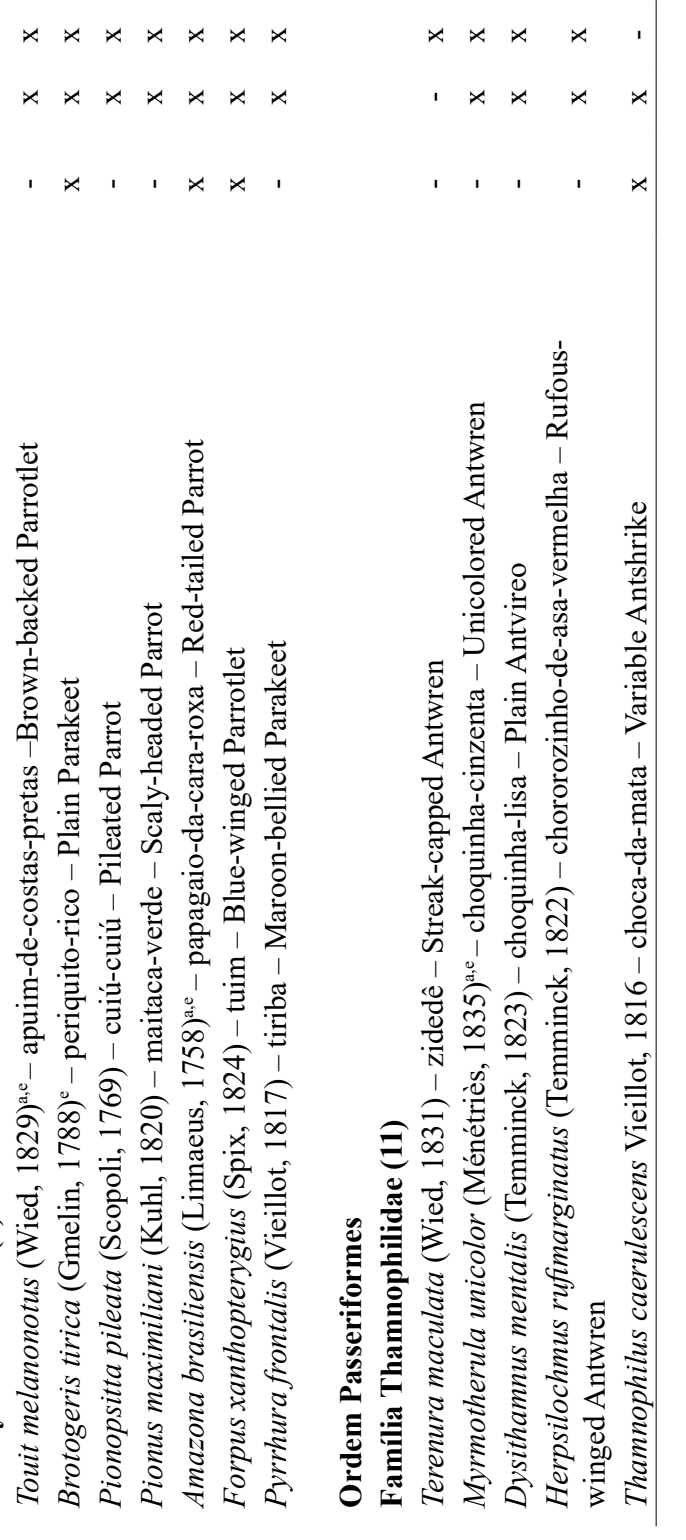


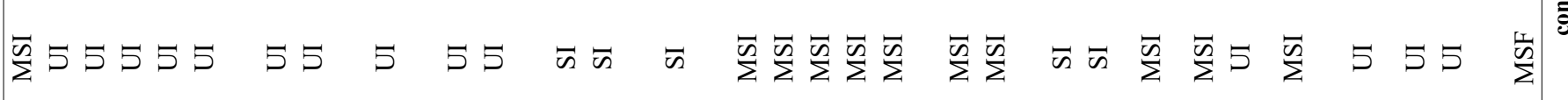

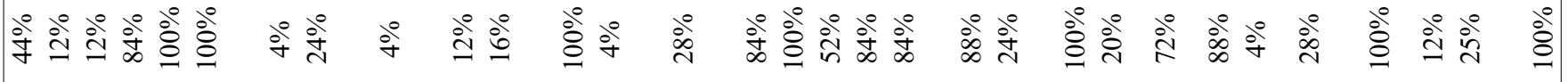

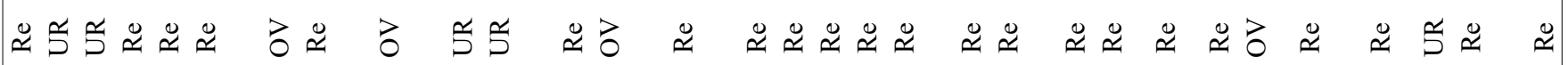

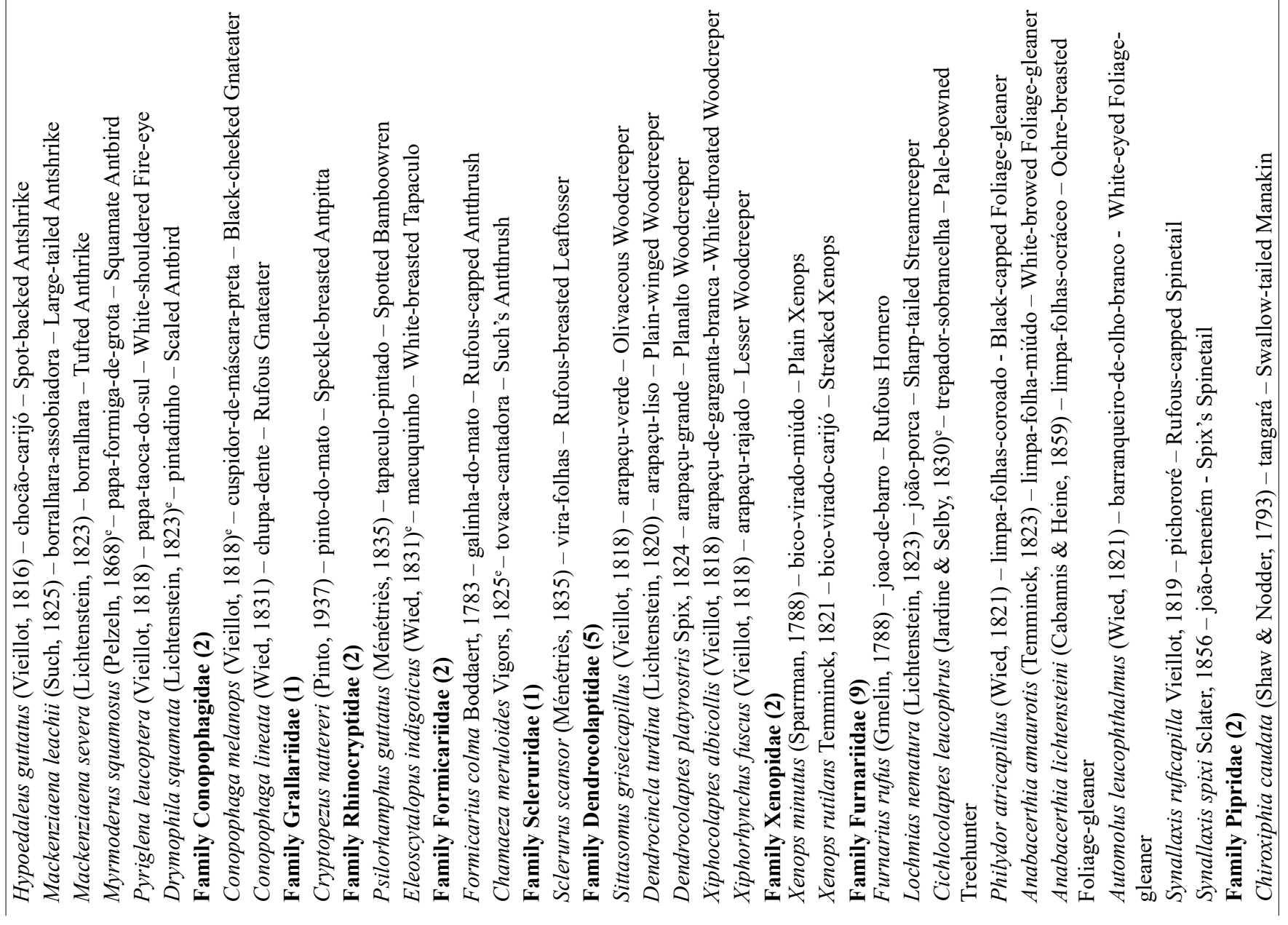


Birds of Parque Estadual Ilha do Cardoso

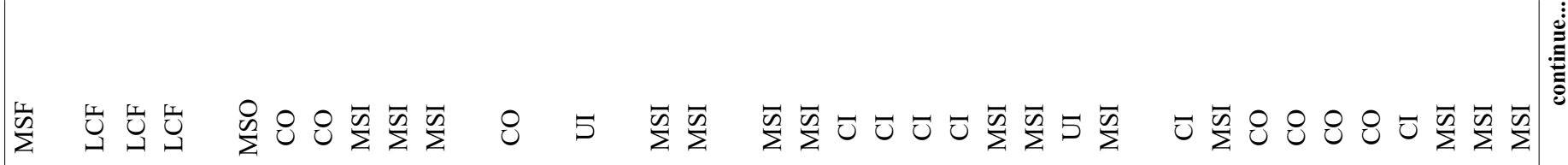

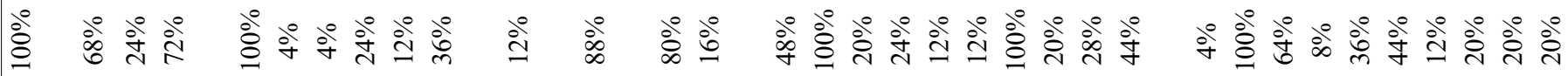

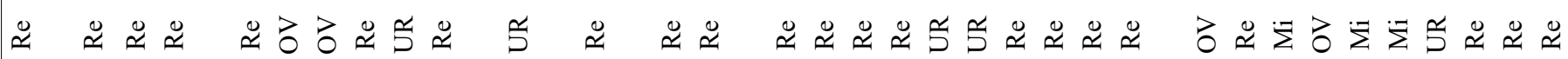

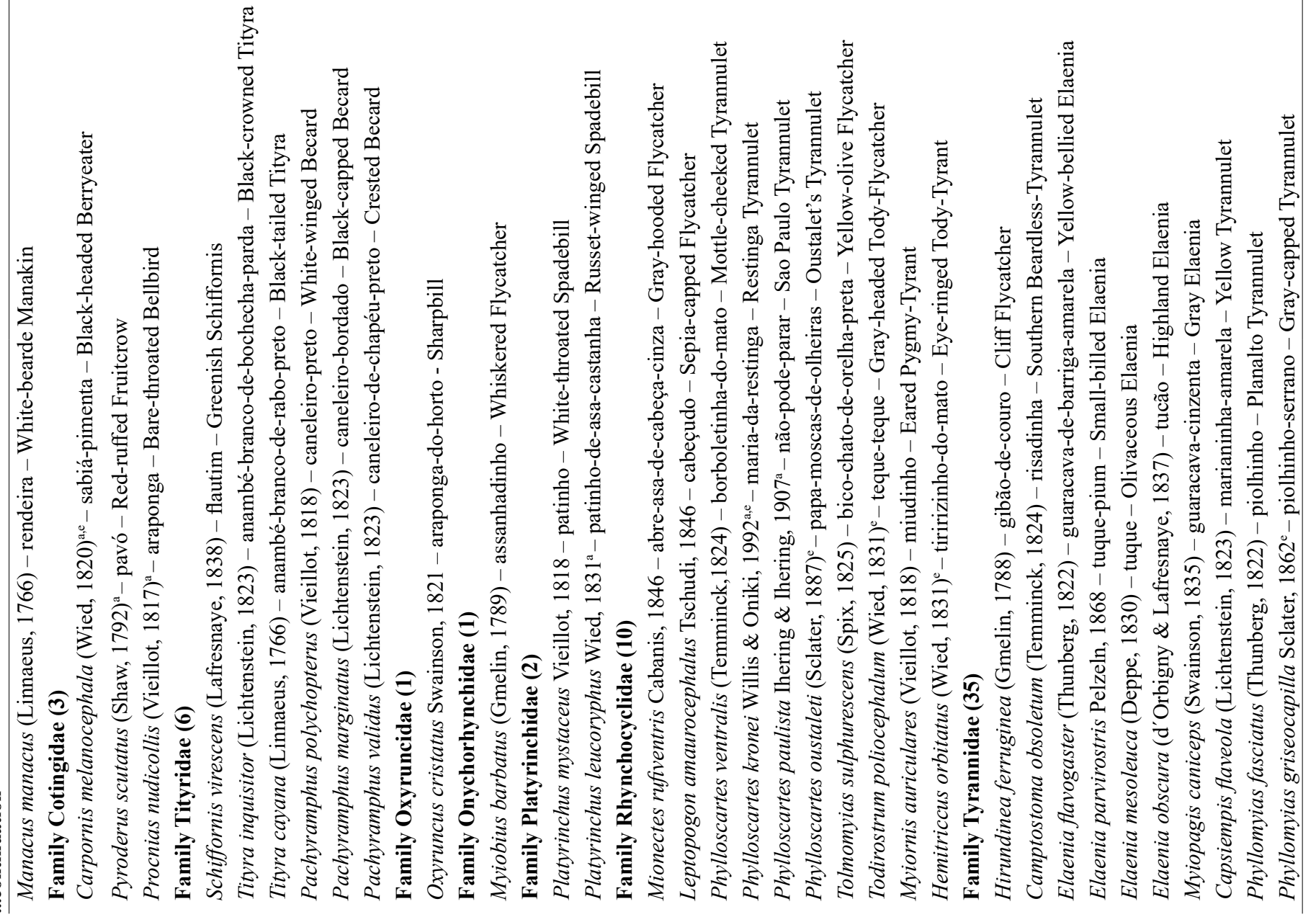




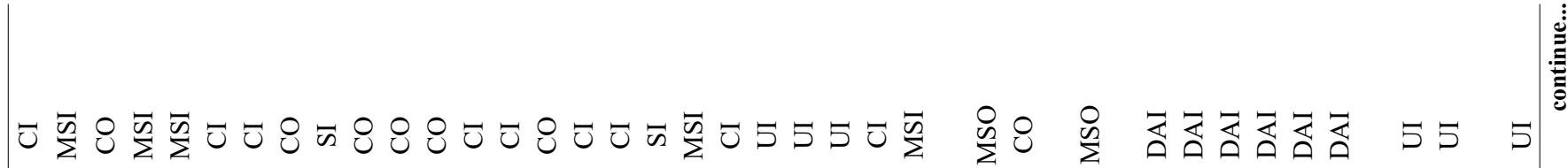

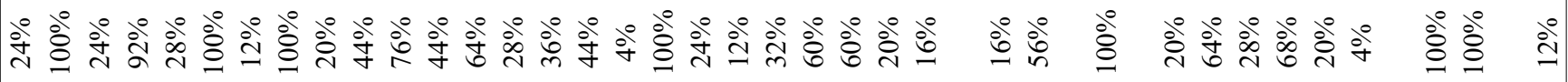

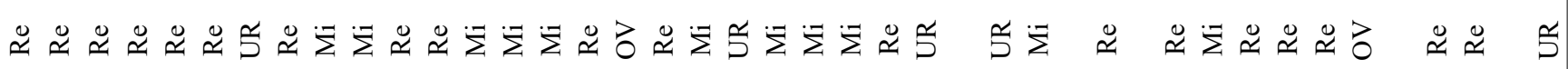

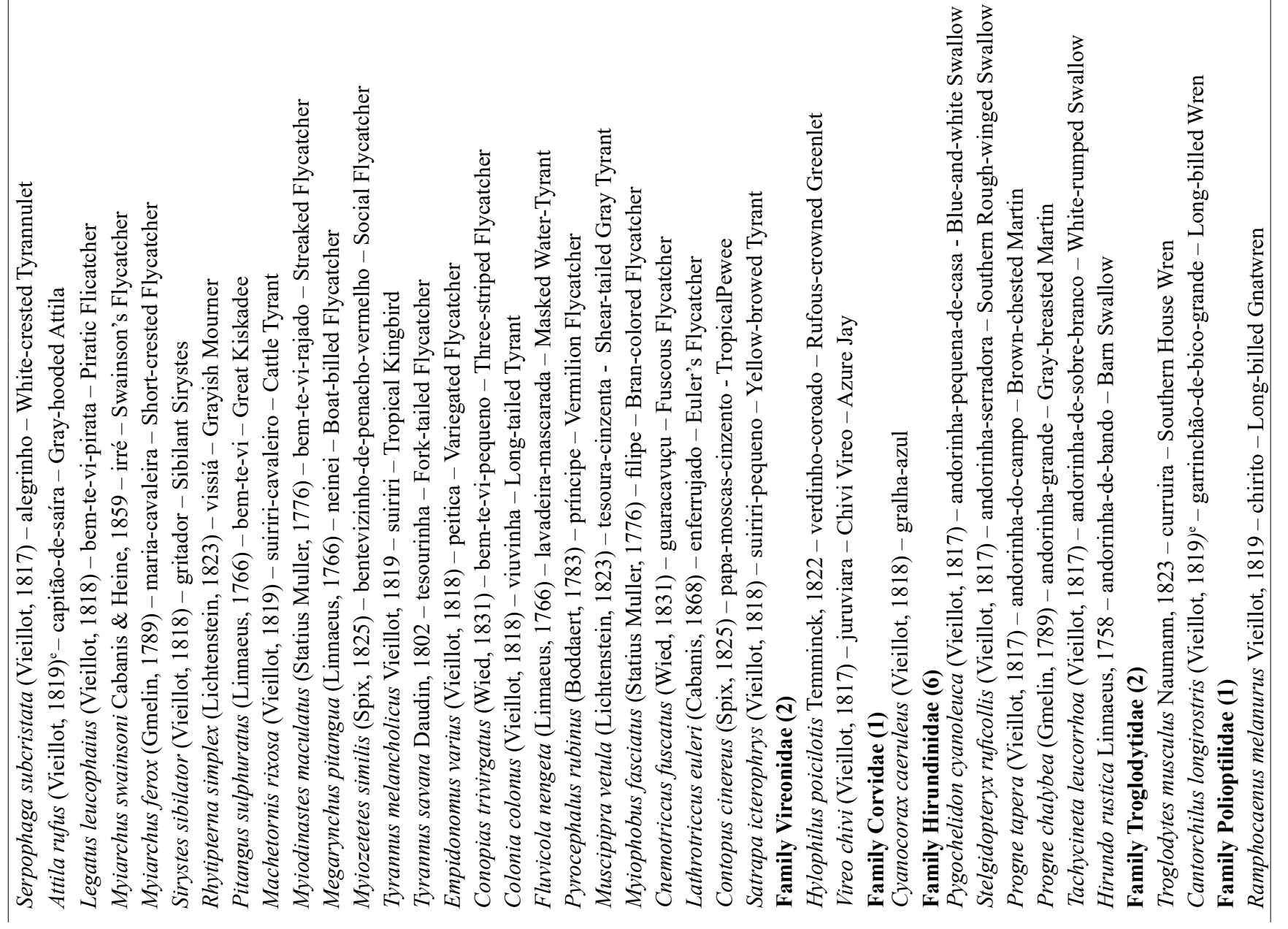


Birds of Parque Estadual Ilha do Cardoso

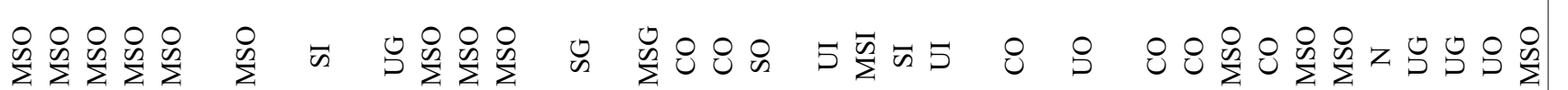

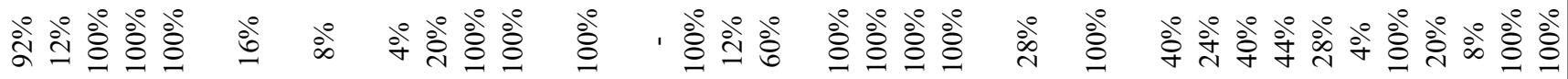

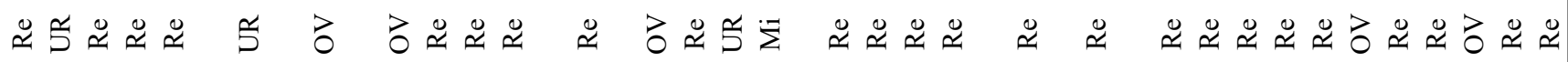

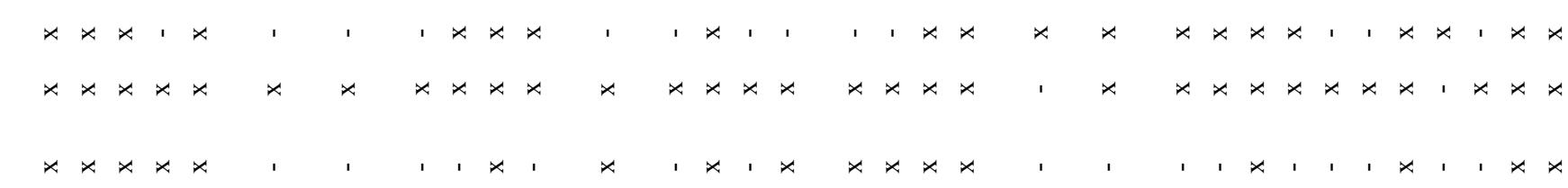

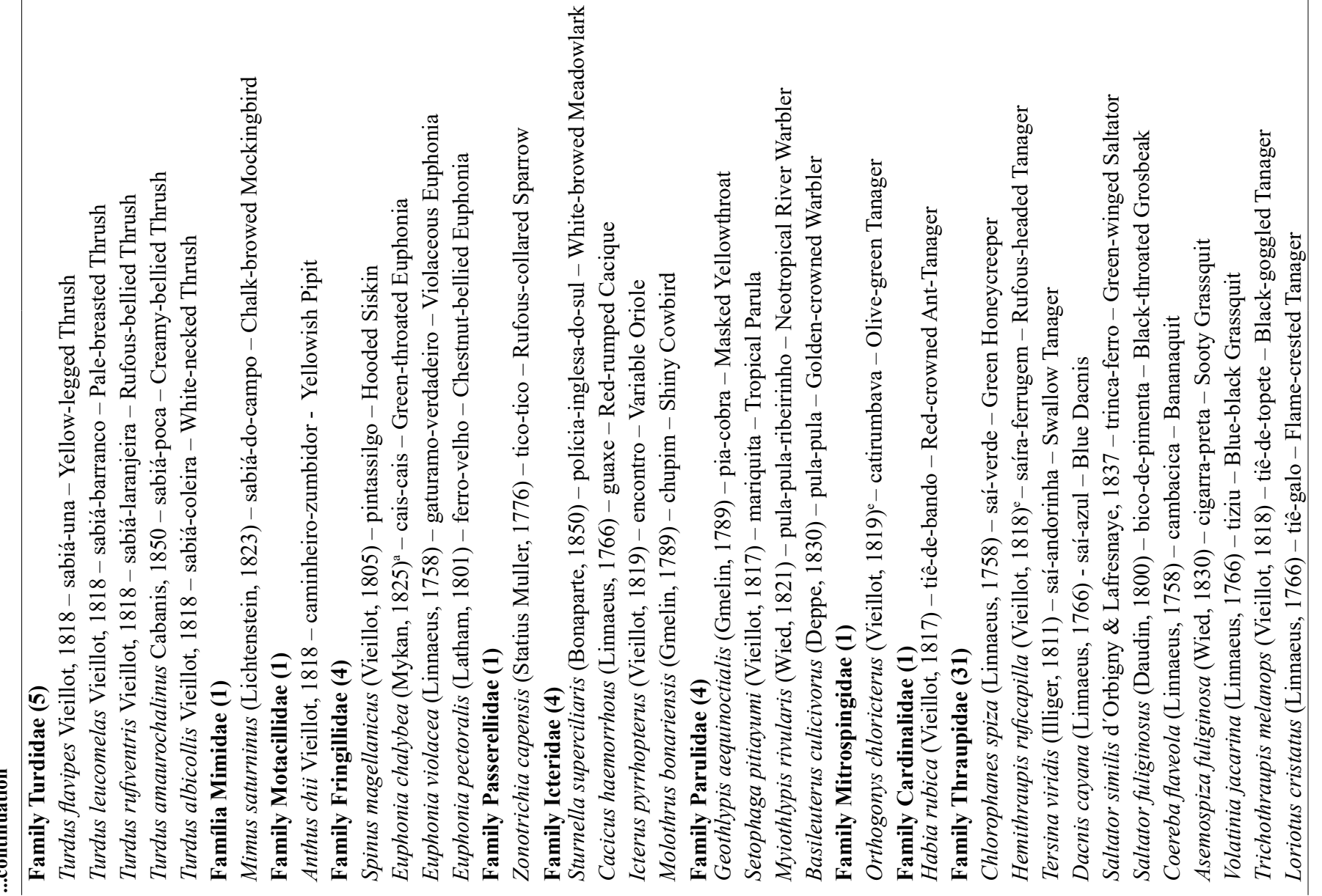


Chupil \& Monteiro-Filho

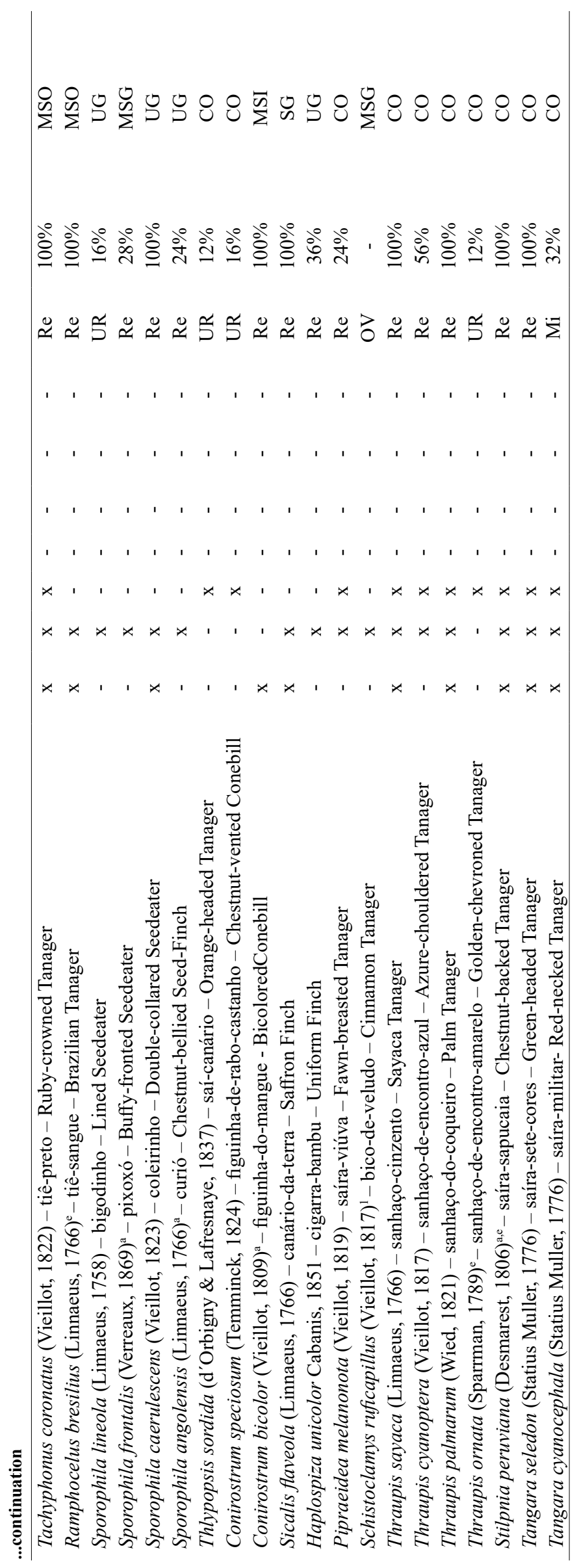




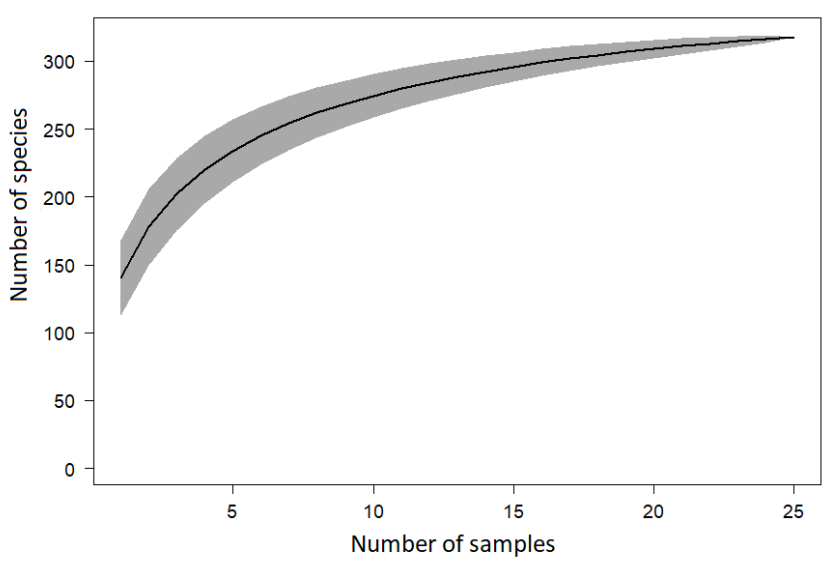

Figure 2. Species accumulation curve to Parque Estadual Ilha do Cardoso (PEIC) avifauna based on 321 species recorded in field (excluded those was recorded by pictures and after to September 2017).

Piping-Guan), Touit melanonotus (Brown-backed Parrotlet) and Carpornis melanocephala (Black-headed Berryeater) (IUCN 2017).

Through use mist-nets, were captured 81 bird's species, which corresponds to $24.3 \%$ of the total species recorded to Parque Estadual Ilha do Cardoso. Despite only one species has been recorded solely by mist-nets (Baryphthengus ruficapillus - Rufus-capped Motmot), is important to pay attention in fact that their utilization made it possible to capture birds which, in certain occasions, would go unnoticed, either by the influence of the year period that turns they less conspicuous or by their ecological habits, as some representatives of families Xenopidae, Onychorhynchidae, Platyrinchidae and Rhynchocyclidae. Accordingly, it is worth mentioning that obtaining a more complete inventory is only possible by using techniques such as visual and auditory contact and mist-nets, reducing possible biases that could be generated, for example, variations in the auditory and visual accuracy of researchers (Karr 1981, Pearman 2002, Dunn \& Ralph 2004).

The restinga was the ecosystem which gathered the biggest number of species $(\mathrm{N}=232)$. This expressive richness could be explained by the fact that in the Northeast portion of the island (sampled area), restinga is between mangrove and forest, receiving influences by both ecosystems for compose its own avifauna. Thus, it is possible that some bird's species occur only eventually in the ecosystem, which are attracted by resources or just by the fact that been moving through the different sections, as occur, for example, with Automolus leucophthalmus (Whiteeyed Foliage-gleaner) which is seen commonly in forest, but in two occasions was detected as part of a mixed flock feeding on insects in restinga's understory.

The high avian richness recorded in mangrove $(\mathrm{N}=118)$, included some species which are typical from forest, such as Xenops rutilans (Streaked Xenops), Mionectes rufiventris (Grey-hooded Flycatcher), Leptopogon amaurocephalus (Sepia-capped Flycatcher), Turdus flavipes (Yellowlegged Thrush) e Ramphodon naevius (Saw-billed Hermit). Sick (2001) had already highlighted how great is richness of species which inhabits mangrove, included some Passeriformes and, mainly, species which feed from aquatic invertebrates and fish. The record of species typically considered forest reinforce the fact of the specie richness on mangrove could be underestimated, what increases the importance of new studies be developed in such ecosystem. In addition, the fact of species considered typical from a specific ecosystem were also recorded in mangrove, could reflect in a bigger plasticity on their part to explore environment, resulting in a better comprehension of their ecological questions.

Concerning forest's richness $(\mathrm{N}=145)$, based on assumption that the sampling was made in the plains, with a maximum lift of $50 \mathrm{~m}$ above sea level, it is possible that in slopes and hilltop, could exist more species which are not recorded in this study, once higher altitudes was explored sporadically. Such hypothesis is based on the fact of the avifauna's composition vary in diversity and abundance along altitudinal gradience (Blake \& Loiselle 2000, Mallet-Rodrigues 2010). Therefore, even though an expressive number of species was being recorded, such richness may still be underestimated.

The species richness showed a significative difference between years and seasons (spring, summer, fall and winter). Concerning richness differences detected between years, there is emphasis on the first sampled year (September 2015 to August 2016) which concentrated a higher amount of rain if compared to the next year (personal observation). Thus, even if the sampling has been made in corresponding weeks and months, adverse weather conditions may have influenced on behavior, and consequently, in species detectability.

Analyzing monthly within seasons, the highest richness was obtained from September to December (spring), justified by the fact that, in this period, the most Brazilian birds start their reproductive activity (Sick 2001), when they end up exposing themselves more (visually or by their vocalizations), what facilitates their record. In PEIC was possible to detect the increase of conspicuity of many species in this time, mainly by the increase of their vocalization, such as Tinamus solitarius (Solitary Tinamou), Odontophorus capueira (Spot-winged Wood-Quail), Trogon viridis (Green-backed Trogon), Pyriglena leucoptera (White-shouldered Fire-Eyed), M. rufiventris, Chiroxiphia caudata (Swallow-tailed Manakin), Turdus spp. and Euphonia spp.

Another important factor which directly contributed to the richness increase in the period from September to March (Spring and Summer) is the arrival of migratory species, coming search warmer areas and with food offer, good factors to breed (Alves 2007). In PEIC stands out the arrival of species from genus Elaenia, Tyrannus savanna (Fork-tailed Flycatcher), Tyrannus melancholicus (Tropical Kingbird), Vireo chivi (Chivi Vireo), Stelgidopteryx ruficollis (Southern Rough-winged Swallow), Cnemotriccus fuscatus (Fuscus Flycatcher), Lathrotriccus euleri (Euler's Flycatcher), Myiodynastes maculatus (Streaked Flycatcher) and Empidonomus varius (Variegated Flycatcher). Furthermore, the richness is increased by species in migration routes which uses beaches and sandbar to rest and feed themselves (identified here as "Visitors from South and North Hemisphere"), such as some Procellariiformes and Charadriiformes. 
Chupil \& Monteiro-Filho

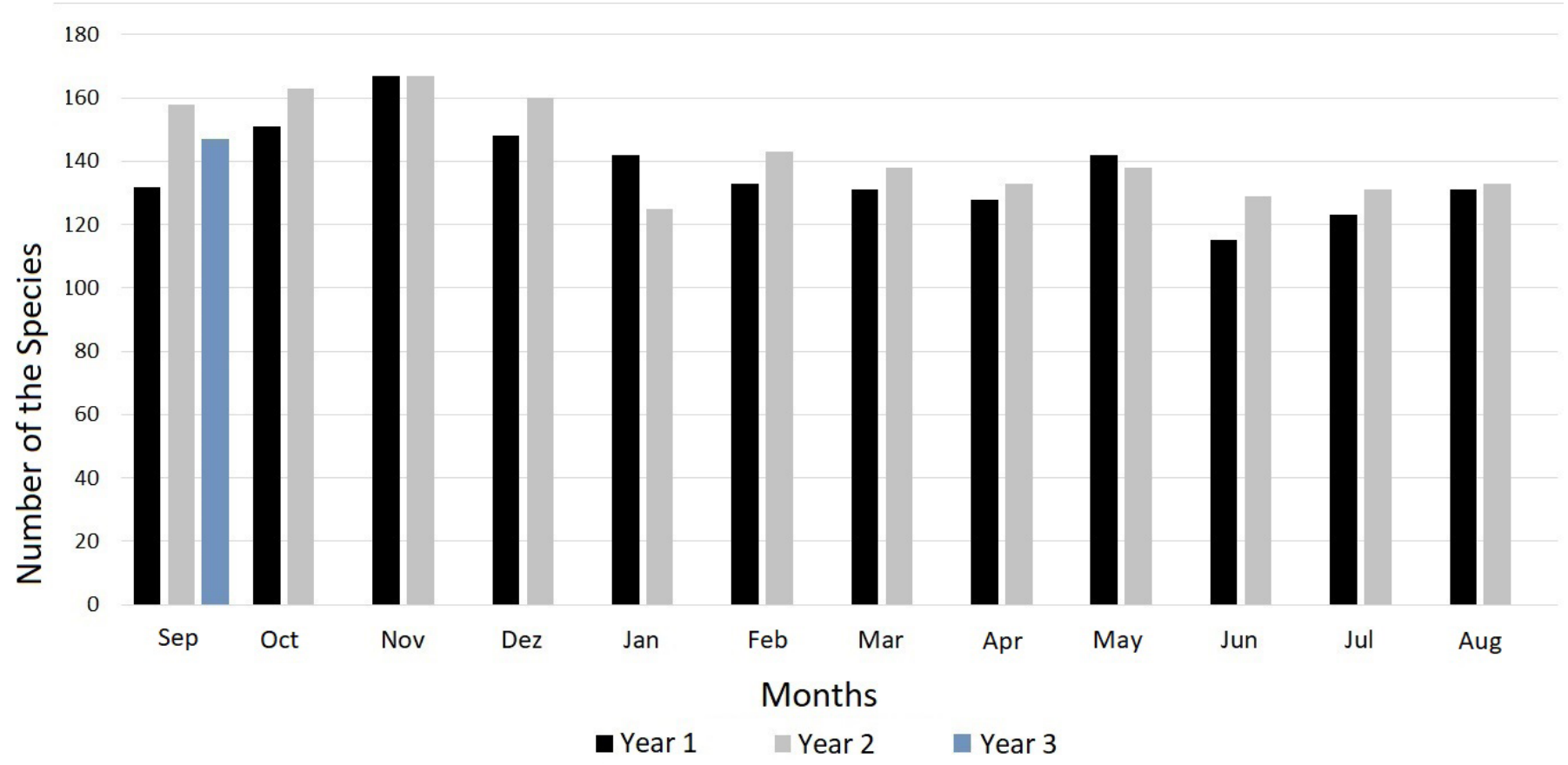

Figure 3. Number of species recorded among sampled months in the period from September 2015 to September 2017 in Parque Estadual Ilha do Cardoso, South coast of São Paulo's State.

The high number of identified guilds $(\mathrm{N}=25)$ could be a reflex of ecosystem diversity that compose the studied area, what provides a vary of niches to be occupied. The fact of the main type of guild, both in mangrove, forest and restinga, be composed of insectivores, is justified, in a first moment, by the fact such resource is abundant in tropical ecosystems (Erwin 1982, Stork 1988, Basset 2012) thus ensuring coexistence of different species. A second factor would be the conservation status of the island, once insectivore birds are susceptible to environmental degradation (Wills 1979, Bierregaard Jr \& Stouffer 1997, Goerck 1997), since in altered environments has a decrease of micro habitats, which leads to a decrease in insect's abundance (Sodhi et al. 2004). In the case of the second more common guild, composed by omnivores, its higher number was expected, since those birds explores a wider range of food items and tend to widely occupy ecosystems, once they don't depend of a specific resource availability (Willis 1979, Anjos \& Bóçon 1999).

In mangrove, the number of omnivores $(\mathrm{N}=30)$ was very similar to the insectivores $(\mathrm{N}=31)$. Such result is interesting because some of these species shows a strongly tendency to frugivory (Sick 2001), and, of these, ten show FO $=100 \%$. Therefore, added to the fact of eight frugivore species also occur in mangrove, it is emphasizing that the richness in such ecosystem could be underestimated if we only evaluate the environmental features when checking species that occur there. These species can regularly occupy this ecosystem (probably with a mostly compound diet by insects) and moving to restinga areas around searching for fruits that complement their diet. Similarly, species which occur in restinga and forest, eventually can moving to the mangrove searching for insects and other invertebrates that are abundant in these ecosystems.
Frugivores, nectivores and granivores species had their occurrence restricted to ecosystems as mangrove, restinga and forest. Between nectivores, four species occurrences in mangrove (Chlorostilbon lucidus - Glittering-bellied Emerald, Ramphodon naevius - Saw-billed Hermit, Thalurania glaucopis - Violet-capped Woodnymph and Coereba flaveola - bananaquit) indicates a higher plasticity by them to explore this environment, once other 11 species of Trochilidae are concentered in restinga and forest. In the $C$. flaveola (Thraupidae) case, the specie was commonly seen caching insects among vegetation; while the three species of Trochilidae were seen exploring flowers from Vrisea, very common in PEIC's mangroves (Barros et al. 1991). There is more frugivores in restinga and forest, ecosystems which reunite many fruitful species that provides food to birds, whereas its occurrence in mangrove can occur only eventually, as previously mentioned. Granivores species recorded are typical from open environment, occur in PEIC mainly in shrub restinga areas and in the transition range with mangrove. In forest ecosystem, the only granivore recorded was Asemospiza fuliginosa (Sooty Grassquit), specie from understory which diet is based mainly on bamboo seeds (Sick 2001).

Carnivores species belonging to Falconiformes and Accipitriformes orders were recorded in all sampled ecosystems, while Strigiformes were seen only on mangrove, restinga and forest. From an ecological point of view, the presence of carnivore birds contributes directly to the ecosystem's balance, once they influence in populational dynamics of their preys (Terborgh 1992, Jaksik 2002). Similar ecological importance applies to scavengers, in PEIC represented by four species (Coragyps atratus - Black Vulture, Cathartes aura - Turkey Vulture, Cathartes burrovianus - Lesser Yellow-headed Vulture and Larus dominicanus - Kelp Gull). The scavengers decrease is taken as a 
Table 2. Species with some level of threat recorded in Parque Estadual Ilha do Cardoso (PEIC) in State Level (S), National Level (N) and Worldwide Level (W). Threat category: CR (Critically Endangered), EN (Endangered), VU (Vulnerable), NT (Near Threatened), LC (Least Concern) and DD (Data Deficient).

\begin{tabular}{|c|c|c|c|}
\hline Species & $\mathbf{S}$ & $\mathbf{N}$ & $\mathbf{W}$ \\
\hline Thalassarche chlororhynchus & VU & $\mathrm{EN}$ & $\mathrm{EN}$ \\
\hline Sterna hirundinacea & NT & VU & $\mathrm{LC}$ \\
\hline Procellaria aequinoctialis & VU & VU & VU \\
\hline Eudocimus ruber & $\mathrm{EN}$ & - & $\mathrm{LC}$ \\
\hline Buteogallus aequinoctialis & $\mathrm{CR}$ & - & NT \\
\hline Amadonastur lacernulatus & VU & VU & VU \\
\hline Pseudastur polionotus & VU & - & NT \\
\hline Spizaetus tyrannus & VU & - & $\mathrm{LC}$ \\
\hline Touit melanonotus & VU & VU & VU \\
\hline Amazona brasiliensis & EM & - & VU \\
\hline Ramphastos vitellinus & $\mathrm{CR}$ & - & VU \\
\hline Selenidera maculirostris & NT & - & $\mathrm{LC}$ \\
\hline Myrmotherula unicolor & VU & - & NT \\
\hline Carpornis melanocephala & $\mathrm{CR}$ & VU & VU \\
\hline Pyroderus scutatus & VU & - & $\mathrm{LC}$ \\
\hline Procnias nudicollis & VU & - & VU \\
\hline Platyrinchus leucoryphus & VU & - & VU \\
\hline Phylloscartes kronei & VU & - & VU \\
\hline
\end{tabular}

serious ecological problem in some parts of the globe, where their decay triggers a trophic cascade process in all community (Buechley \& Şekercioğlu 2016). Thus, the abundance of scavengers in PEIC (except C. burrovianus, with occasional occurrence), is an indicator that nutrient cycling in the environment occur intensively, thus contributing to its balance.

The record of piscivores and invertebrate consumer's species is clustered mainly in beach, sandbar and mangrove ecosystems. Such result reflects richness that characterizes waters around the island and ensure a wide food source to bird species, mainly from Pelecaniformes, Gruiformes, Suliformes and Charadriiformes orders. Here we include the Procellariiformes within the "Piscivore" guild, however, it is worth mentioning that the composition of the diet of this taxon varies seasonally, with the predominance of fish or cephalopods (Vooren \& Fernandes 1989).

The richness of species mentioned in this study, highlights the importance of preserving forest remnants in coastal regions of São Paulo's State, aiming to maintain Atlantic Forest diversity. Finally, this study, made through a great field effort ( 25 months) bring a better knowledge of PEIC's avifauna, such effort that should serve as basis for establishing actions aimed ate the management of the park as well as the conservation units that are distributed in its surroundings. 
Table 3. Total number of species and specie/ecosystem recorded in Parque Estadual Ilha do Cardoso (SP) among each trophic guild. Bold values correspond to ecosystem which take the biggest number of specie within each guild. In the squares values correspond to the main guild in each ecosystem. Caption: C - Whole Community; M-Mangrove; R - Restinga; F - Forest; Sb - Sand-bar; B - Beach; Mr - Marine; Fl - Flying.

\begin{tabular}{|c|c|c|c|c|c|c|c|c|}
\hline Canopy Omnivores & 33 & 15 & 25 & 21 & 1 & 0 & 0 & 0 \\
\hline Aquatic Invertebrates Consummers & 31 & 14 & 5 & 1 & 7 & 10 & 0 & 0 \\
\hline Daytime Carnivores & 24 & 7 & 12 & 11 & 1 & 5 & 2 & 3 \\
\hline Understory Insectivores & 23 & 4 & 19 & 14 & 0 & 0 & 0 & 0 \\
\hline Canopy Insectivores & 16 & 1 & 13 & 6 & 0 & 0 & 0 & 0 \\
\hline Nectarivores & 15 & 4 & 15 & 6 & 0 & 0 & 0 & 0 \\
\hline Large Canopy Frugivores & 11 & 4 & 9 & 9 & 0 & 0 & 0 & 0 \\
\hline Daytime Aerial Insectivores & 11 & 4 & 6 & 0 & 0 & 0 & 0 & 5 \\
\hline Soil Insectivores & 10 & 3 & 7 & 5 & 1 & 1 & 0 & 0 \\
\hline Nocturnal Carnivores & 6 & 1 & 5 & 1 & 0 & 0 & 0 & 0 \\
\hline Aquatic Omnivores & 6 & 2 & 3 & 0 & 1 & 1 & 0 & 0 \\
\hline Small-Medium Canopy Frugivores & 5 & 2 & 5 & 5 & 0 & 0 & 0 & 0 \\
\hline Scavengers & 4 & 3 & 2 & 2 & 2 & 4 & 1 & 0 \\
\hline Soil Granivores & 4 & 3 & 4 & 0 & 0 & 0 & 0 & 0 \\
\hline Medium-strata Granivores & 3 & 0 & 3 & 0 & 0 & 0 & 0 & 0 \\
\hline Medium-strata Frutivores & 2 & 0 & 2 & 1 & 0 & 0 & 0 & 0 \\
\hline Understory Omnivores & 2 & 1 & 2 & 2 & 0 & 0 & 0 & 0 \\
\hline Soil Omnivores & 1 & 1 & 1 & 0 & 0 & 0 & 0 & 0 \\
\hline
\end{tabular}

\section{Acknowledgments}

To all people who helped in field works, especially to Priscila Lemes Gross and Fabiana Silveira. Also, thanks to all support and friendship of employees and local residents of Parque Estadual Ilha do Cardoso. Finally, we dedicate this study to mister Reinaldo R. Ribeiro (in memoriam), to his companionship, friendship and support in some boat expeditions to the island.

\section{Author Contributions}

Henrique Chupil: Substantial contribution in the concept and design of the study; Contribution to data collection; Contribution to data analysis and interpretation; Contribution to manuscript preparation; Contribution to critical revision, adding intelectual content.

Emygdio Leite de Araujo Monteiro-Filho: Substantial contribution in the concept and design of the study; Contribution to data analysis and interpretation; Contribution to critical revision, adding intelectual content.

\section{Conflicts of Interest}

The author(s) declare(s) that they have no conflict of interest related to the publication of this manuscript.

\section{References}

ALVES, LA DE 2008. Estrutura da comunidade de morcegos (Mammalia: Chiroptera) do Parque Estadual da Ilha do Cardoso, São Paulo, SP. Dissertação (Mestrado em Ecologia e Conservação), Universidade de São Paulo.

ALVES, MAS 2007. Sistemas de migrações de aves em ambientes terrestres no Brasil: exemplos, lacunas e propostas para o avanço do conhecimento. Rev. Bras. Ornitol. 15 (2): 243-250.

ANJOS, L \& BÓÇON, R 1999. Bird communities in natural forest patches in southern Brazil. Wilson. J. Ornithol. 111 (3) 397-414.

BARROS, F., MELO, MMRF., CHIEA, SAC., KIRIZAWA, M., WANDERLEY, MGL \& JUNG-MENDAÇOLLI, S 1991. Flora fanerogâmica da Ilha do Cardoso - Caracterização geral da vegetação e listagem das espécies ocorrentes. Instituto de Botânica. São Paulo, v.1.

BASSET, Y., CIZEK, L., CUÉNOUD, P., DIDHAM, RK., GUILHAUMON, F., MISSA, O., NOVOTNY, V., ØDEGAARD, F., ROSLIN, T., SCHMIDL, J., TISHECHKIN, AK., WINCHESTER, NN., ROUBIK, DW., ABERLENC, HP., BAIL, J., BARRIOS, H., BRIDLE, JR., CASTAÑO-MENESES, G., CORBARA, B., CURLETTI, G., DA ROCHA, WD., BAKKER, D., DELABIE, JHC., DEJEAN, A., FAGAN, LL., FLOREN, A., KITCHING, RL., MEDIANERO, E., MILLER, SE., OLIVEIRA, EG., ORIVEL, J., POLLET, M., RAPP, M., RIBEIRO, SP., ROISIN, Y., SCHMIDT, JB., SØRENSEN, L \& LEPONCE, M 2012. Arthropod diversity in a tropical forest. Science. 338 (6113) 1481-1484.

BERTOLUCI, J., BRASSALOTI, RA., RIBEIRO JÚNIOR, JW., VILELA, VMDFN \& SAWAKUCHI, HO 2007. Species composition and similarities among anuran assemblages of forest sites in southeastern Brazil. Sci. Agric. 64 (4) $364-374$. 
BIERREGAARD JR, RO \& STOUFFER, PC 1997. Understory birds and dynamic habitat mosaics in Amazonian Rainforests. In: LAURANCE, WF \& BIERREGAARD JR, RO. (Eds). Tropical Forest Remnants. University of Chicago Press, Chicago. p.138-155.

BLAKE, JG \& LOISELLE, BA 2000. Diversity of birds along an elevational gradient in the Cordillera Central, Costa Rica. The Auk. 117 (3) 663-686.

BROOKS, T \& BALMFORD, A 1996. Atlantic forest extinctions. Nature. 380 (6570) 115

BUECHLEY, E. R \& ŞEKERCIOĞLU, Ç. H. 2016. The avian scavenger crisis: looming extinctions, trophic cascades, and loss of critical ecosystem functions. Biol Conserv. 198, 220-228.

CIIAGRO. Centro Integrado de Informações Agrometeorológicas. Disponível em http://www.ciiagro.sp.gov.br/ciiagroonline/Quadros/. Acessado em 20/11/2018.

DEVELEY, PF 2004. Efeitos da fragmentação e do estado de conservação da floresta na diversidade de aves de Mata Atlântica. Tese de Doutirado. Universidade de São Paulo.

ERWIN, TL 1982. Tropical forests: their richness in Coleoptera and other arthropod species. Coleopt Bull. 36 (1) 74-75.

GOERCK, JM 1997. Patterns of rarity in the birds of the Atlantic forest of Brazil. Conserv. Biol. 11, 112-118.

HAMMER, Ø., HARPER, DAT. \& RYAN, PD 2001. PAST: Paleontological Statistics Software Package for Education and Data Analysis. Palaeontologia Electronica.

HAWKINS, BA., FIELD, R., CORNELL, HV., CURRIE, DJ., GUÉGAN, JF., KAUFMAN, DM., KERR, JT., MITTELBACH, GG., OBERDORFF, T., EILEEN, M., O'BRIEN, EM., PORTER, EE \& TURNER. JRG 2003. Energy, water, and broad-scale geographic patterns of species richness. Ecology. 84, 3105-3117.

IUCN - RED LIST OF THREATENED SPECIES. Disponível em: < http:// www.iucnredlist.org/>. Acesso em: 11 de maio de 2018.

JAKSIC, F., IRRIARTE, JA. \& JUMÉNEZ, JE 1992. The raptors of Torres del Paine National Park, Chile: biodiversity and conservation. Rev. Chil. Hist. Nat. 75, 449-461.

JOHNS, AD 1991. Responses of Amazonian rain forest birds to habitat modification. J. Trop. Ecol. 7 (4) 417-437.

KARR, JR \& FREEMARK, KE 1983. Habitat selection and environmental gradients: dynamics in the" stable" tropics. Ecology, 64 (6) 1481-1494.

KISSLING, WD., SEKERCIOGLU, CH \& JETZ, W 2012. Bird dietary guild richness across latitudes, environments and biogeographic regions. Global Ecol. Biogeogr. 21 (3) 328-340.

MALLET-RODRIGUES, F., PIMENTEL, PR., LEONARDO MS \& BESSA, R. Altitudinal distribution of birds in a mountainous region in southeastern Brazil. Zoologia. 27 (4) 503-522.

MARSDEN, SJ., WHIFFIN, M., SADGROVE, L \& GUIMARÃES, PRJR 2004. Bird community composition and species abundance on two inshore islands in the Atlantic forest region of Brazil. Ararajuba. 11, 29-36.

MARTERER, BTP 1996. Avifauna do Parque Botânico Morro do Baú. Riqueza, aspectos de frequência e abundância. Santa Catarina: FATMA.

MARTÍN, PV., HIDALGO, J., DE CASAS, RR \& MUÑOZ, MA 2016. Ecoevolutionary model of rapid phenotypic diversification in species-rich communities. PLoS Comp. Biol. 12 (10) e1005139.

MARTINS, F 2013. Marsupiais e roedores em ambientes costeiros terrestres no sul do Estado de São Paulo. Dissertação (Mestrado em Zoologia), Universidade Federal do Paraná.

MINISTÉRIO DO MEIO AMBIENTE - MMA 2014. Lista Nacional Oficial das Espécies da Fauna Brasileira Ameaçadas de Extinção. Portaria n. 444, de 17 de dezembro de 2014. Diário Oficial da República Federativa do Brasil, Brasilia, DF. Seção 1, 245, p. 121-126.

MORANTE-FILHO, JC., FARIA, D., MARIANO-NETO, E \& RHODES, J 2015. Birds in anthropogenic landscapes: the responses of ecological groups to forest loss in the Brazilian Atlantic Forest. PLoS One. 10 (6) e0128923.

MIYAO, SY., NISHIHARA, L \& SARTI, CC 1986. Características físicas e químicas do sistema estuarino lagunar de Cananéia-Iguape. Bol. Inst. Ocean. 34, 23-36.
NAKANO-OLIVEIRA, E 2006. Ecologia e conservação de mamiferos carnivoros de Mata Atlantica na região do compelxo estuarino lagunar de Cananeia, Estado de São Paulo. Tese (Doutorado em Ecologia), Universidade Estadual de Campinas.

NEGREIROS, OC., CARVALHO, CT., CESAR, SF., DUARTE, FR., DESHLER, WO \& THELEN, KD 1974. Plano de manejo para o Parque Estadual da Ilha do Cardoso. Bol. Téc. Inst. Flor. 9, 1-57.

PACHECO, J.F.; SILVEIRA, L.F.; ALEIXO, A.; AGNE, C.E.; BENCKE, G.A.; BRAVO, G.A; BRITO, G.R.R.; COHN-HAFT, M.; MAURÍCIO, G.N.; NAKA, L.N.; OLMOS, F.; POSSO, S.; LEES, A.C.; FIGUEIREDO, L.F.A.; CARRANO, E.; GUEDES, R.C.; CESARI, E.; FRANZ, I.; SCHUNCK, F \& PIACENTINI, V.Q. 2021. Annotated checklist of the birds of Brazil by the Brazilian Ornithological Records Committee - second edition. Ornithology Research. 29 (2) 1-123.

PEREIRA, GA., DANTAS, SDM., SILVEIRA, LF., RODA, SA., ALBANO, C., SONNTAG, FA., LEAL, S., PERIQUITO, MC., MALACCO, GB \& LEES, AC 2014. Status of the globally threatened forest birds of northeast Brazil. Pap. Avulsos Zool. 54 (14) 177-194.

PINHEIRO, SCP 2009. Anurofuna de serapilheira de diferentes formaçõesvegetais ao longo de um gradiente altitudinal no Parque Estadual da Ilha do Cardoso, município de Cananéia, SP. Dissertação (Mestrado em Ecologia Aplicada), Universidade de São Paulo, São Paulo.

PRIMACK, R \& RODRIGUES, E 2001. Biologia da conservação. Londrina: Planta.

REIF, J., VERMOUZEK, Z., VOŘÍŠEK, P., ŠŤASTNÝ, K., BEJČEK, V. \& FLOUSEK, J 2010. Population changes in Czech passerines are predicted by their life-history and ecological traits. Ibis. 152 (3) 610-621.

RICKLEFS, RE 2003. A economia da natureza. 5a. Ed. Rio de Janeiro: Guanabara

RIDGELY, RS., GWYNNE, JA., TUDOR, G \& ARGEL. M 2015. Aves do Brasil - Mata Atlântica do Sudeste, São Paulo: Editora Horizonte.

ROCHA, C., BERGALLO, HG., CONDE, V., FABIANE, C., BITTENCOURT, EB. \& SANTOS, HDC 2008. Frederico Duarte et al. Richness, abundance, and mass in snake assemblages from two Atlantic Rainforest sites (Ilha do Cardoso, São Paulo) with differences in environmental productivity. Biota Neotrop. 8 (3) 0-0. https://doi.org/10.1590/S1676-06032008000300011. Último acesso em 27/06/2020.

SÃO PAULO (Estado). Secretaria do Meio Ambiente. Instituto Florestal 1998. Plano de gestão ambiental - fase 1 do Parque Estadual da Ilha do Cardoso. São Paulo.

SÃO PAULO (Estado). Secretaria do Meio Ambiente. Instituto Florestal 2002. Plano de gestão ambiental - fase 2 do Parque Estadual da Ilha do Cardoso. São Paulo.

SERRA, A \& PISCIOTA, K 2002. Census of vertebrates in a Brazilian Atlantic forest área: the Paranapiacaba fragmente. Barcelona: Universitat de Barcelona.

SCHAEFFER-NOVELLI, Y., MESQUITA, HSL \& CINTRÓN-MOLERO, G 1990. The Cananéia Lagoon Estuarine System, São Paulo, Brazil. Estuaries. 13 (2) 193-203.

SICK, H 2001. Ornitologia brasileira. $2^{\mathrm{a}}$ Ed, Rio de Janeiro: Nova Fronteira.

SILVEIRA, F 2017. Uso de estrato vertical por pequenos mamíferos no Parque Estadual da Ilha do Cardoso. Tese (Doutorado em Zoologia) Universidade Federal do Paraná.

SILVEIRA, LF., BENEDICTO, GA., SCHUNCK, F. \& SUGIEDA, AM 2009. Aves. In. BRESSAN, PM., KIERULFF, MCM \& SUGIEDA, AM (Eds) Fauna ameaçada de extinção no Estado de São Paulo: vertebrados, Fundação Parque Zoológico de São Paulo: Secretaria do Meio Ambiente.

SODHI, NS., LIOW, LH., BAZZAZ, FA 2004. Avian extinction from tropical and subtropical forests. Annual Review of Ecology, Evol. Syst. 35 - 323-345.

SOS MATA ATLÂNTICA 2015. Atlas da evolução dos remanescentes florestais e ecossistemas associados no domínio da mata atlântica no período 20132014. São Paulo: Fundação SOS Mata Atlântica/INPE.

SOS MATAATLÂNTICA 2017. Atlas da evolução dos remanescentes florestais e ecossistemas associados no domínio da mata atlântica no período 20152016. São Paulo: Fundação SOS Mata Atlântica/INPE 
Chupil \& Monteiro-Filho

STORK, NE 1988. Insect diversity: facts, fiction and speculation. Biol. Journ. Linn. Soc. 35 (4) 321-337.

TERBORGH, J 1992. Maintenance of diversity in tropical forest. Biotropica. 24, 283-292.

VILELA, VMFN., BRASSALOTI, RA \& BERTOLUCI, J 2011. Anurofauna da floresta de restinga do Parque Estadual da Ilha do Cardoso, Sudeste do Brasil: composição de espécies e uso de sítios reprodutivos. Biota Neotrop. 11 (1) 0-0. http://dx.doi.org/10.1590/S1676-06032011000100008. Último acesso em 27/06/2020.

VOOREN, CM \& FERNANDES, AC 1989. Guia de albatrozes e petréis do sul do Brasil. Editora Sagra.
WILLIS, EO 1979. The composition of avian communities in remanescent woodlots in southern Brasil. Pap. Avul. Zool. 33, 1-25.

ZINA, J., PRADO, CPDA., BRASILEIRO, CA., HADDAD, CFB 2012. Anurans of the sandy coastal plains of the Lagamar Paulista, State of São Paulo, Brazil. Biota Neotrop. 12 (1) 251-260. https://doi.org/10.1590/S167606032012000100020. Último acesso em 27/06/2020.

Received: 08/10/2021

Accepted: 01/11/2021

Published online: 14/01/2022 